Cronfa - Swansea University Open Access Repository

This is an author produced version of a paper published in :

Quaternary Science Reviews

Cronfa URL for this paper:

http://cronfa.swan.ac.uk/Record/cronfa18286

\title{
Paper:
}

Bourne, A., Cook, E., Abbott, P., Seierstad, I., Steffensen, J., Svensson, A., Fischer, H., Schüpbach, S. \& Davies, S. (2015). A tephra lattice for Greenland and a reconstruction of volcanic events spanning 25-45 ka b2k. Quaternary Science Reviews, 118, 122-141.

http://dx.doi.org/10.1016/j.quascirev.2014.07.017

This article is brought to you by Swansea University. Any person downloading material is agreeing to abide by the terms of the repository licence. Authors are personally responsible for adhering to publisher restrictions or conditions. When uploading content they are required to comply with their publisher agreement and the SHERPA RoMEO database to judge whether or not it is copyright safe to add this version of the paper to this repository. http://www.swansea.ac.uk/iss/researchsupport/cronfa-support/ 


\section{A tephra lattice for Greenland and a reconstruction of volcanic events}

\section{2 spanning 25-45 ka b2k}

3

4 Bourne, A.J. ${ }^{*}$, Cook, E. ${ }^{1}$, Abbott, P.M. ${ }^{1}$, Seierstad, I.K., ${ }^{2}$ Steffensen, J.P. ${ }^{2}$, Svensson, A. ${ }^{2}$, $5 \quad$ Fischer, H. ${ }^{3}$, Schüpbach, S. ${ }^{3}$, Davies, S.M. ${ }^{1}$

6

$7 \quad{ }^{1}$ Department of Geography, College of Science, Swansea University, Swansea, UK

$8{ }^{2}$ Centre for Ice and Climate, Niels Bohr Institute, University of Copenhagen, Denmark

$9{ }^{3}$ Climate and Environmental Physics, Physics Institute, University of Bern, Switzerland

11 *Corresponding Author. Email: a.j.bourne@swansea.ac.uk

\section{Abstract}

Tephra layers preserved within the Greenland ice-cores are crucial for the independent synchronisation of these high-resolution records to other palaeoclimatic archives. Here we present a new and detailed tephrochronological framework for the time period 25,000 45,000 yrs b2k that brings together results from 4 deep Greenland ice-cores. In total, 99 tephra deposits, the majority of which are preserved as cryptotephra, are described from the NGRIP, NEEM, GRIP and DYE-3 records. The major element signatures of single glass shards within these deposits indicate that 93 are basaltic in composition with 43 originating from Grimsvötn, 20 are thought to be sourced from the Katla volcanic system and 17 show affinity to the Kverkfjöll system. Robust geochemical characterisations, independent ages derived from the GICC05 ice-core chronology, and the stratigraphic positions of these deposits relative to the Dansgaard-Oeschger climate events represent a key framework that provides new information on the frequency and nature of volcanic events in the North 
26 Atlantic region between GS-3 and GI-12. Of particular importance are 19 tephra deposits

27 that lie on the rapid climatic transitions that punctuate the last glacial period. This framework of well-constrained, time-synchronous tie-lines represents an important step towards the independent synchronisation of marine, terrestrial and ice-core records from the North Atlantic region, in order to assess the phasing of rapid climatic changes during the last glacial period.

\section{Keywords}

Tephrochronological framework; tephrostratigraphy; cryptotephra; Greenland ice-cores; Iceland; rapid climate changes

\section{Introduction}

The Greenland ice-cores have provided an unprecedented insight into the nature of abrupt climatic changes (Dansgaard-Oeschger (DO) events) during the last glacial period (e.g. Dansgaard et al 1993; NGRIP members, 2004). With an independent annually-resolved chronology (Andersen, et al., 2006, Rasmussen et al., 2006; Svensson et al., 2006; Vinther et al., 2006), these records represent significant archives for establishing the history of volcanic events during this time-interval. Both volcanic aerosol (ice acidity and sulphate records) and tephra particulate matter (or glass shards) preserved in the ice permit the reconstruction of volcanic history, but only the volcanic glass shards allow the geochemical identification of the volcanic source and their employment as isochronous marker horizons between disparate archives. A major disparity exists between the number of volcanic events recorded by these two methods, with over 800 events being identified in the GISP2 sulphate record over the 
past 110,000 years (Zielinski et al., 1996) but only 68 tephra deposits have been recognised to date from four of the deep ice-cores (Abbott and Davies, 2012 and references therein; Coulter et al., 2012; Bourne et al., 2013). As such, there is untapped potential to explore the full record of tephra deposits in the Greenland ice-cores as early work focused predominantly on the presence of easily identifiable visible layers (Grönvold et al., 1995, Zielinski et al., 1996). More recently investigations have moved to search for cryptotephra deposits that contain a low concentration of volcanic glass particles or shards and, as such, are invisible to the naked eye (e.g. Abbott et al., 2012; Davies et al., 2010; Coulter et al., 2012). However these studies focused on a limited number of samples, typically around peaks in ice acidity and sulphate thought to relate to volcanic activity. It has become apparent, however, that in some instances, glass shards from volcanic events can be present in the ice without an associated acidity or sulphate peak suggesting the relationship between the two records of volcanism may be more complex than previously thought (e.g. Davies et al., 2010, in press).

Here we investigate the cryptotephra content within four deep ice-cores from Greenland spanning 25-45 ka b2k as part of the TRACE project (Tephra constraints on RApid Climate Events). TRACE employs tephra deposits to facilitate the high-precision correlation of palaeoclimatic archives that preserve a record of rapid climate changes that characterised the last glacial period. A systematic search for cryptotephra deposits is undertaken to reduce an over-reliance on chemical indicators in order to build a comprehensive framework of volcanic events preserved within Greenland ice-core records. A lattice of this kind, which combines robust geochemical signatures with well-constrained age estimates, is essential for the wider application of tephrochronology and especially to circumvent any potential miscorrelation that may arise due to an incomplete record of volcanic history. Common tephra deposits that can be traced between the Greenland ice-cores and North Atlantic marine 
records will provide a robust chronological foundation to test the lead/lag relationships between the atmospheric and oceanic systems over rapid climatic events and permit an assessment of potential causal mechanisms. We report the discovery of 73 new tephra deposits - all of which are available for the precise correlation of marine, terrestrial and icecore records spanning 25 - $45 \mathrm{ka} \mathrm{b} 2 \mathrm{k}$. This framework represents a significant advancement on the previously published results from this period with just 26 tephra deposits identified in the Greenland ice-cores by Davies et al., (2010) and Bourne et al., (2013). We highlight which of the deposits are potentially most valuable for the synchronisation of palaeoclimate archives. Moreover, our focus on four different ice-cores, provides an insight into the tephra dispersal and preservation patterns over the Greenland ice sheet and also presents an independent method (and test) by which an ice-core chronology can be transferred between cores.

Until recently only a handful of tephras could be traced between different ice-cores including the widespread Saksunarvatn and North Atlantic Ash Zone II (NAAZII; Z2) deposits identified as visible layers in three ice-cores (Grönvold et al., 1995; Ram et al., 1996; Zielinski et al., 1997; Mortensen et al., 2005; Svensson et al., 2008). Recently, however, the intensified focus on cryptotephra deposits in different ice-cores has allowed Rasmussen et al., (2013) to use 5 new coeval tephras in NEEM and NGRIP in tandem with acidity match points to transfer the GICC05 timescale to the NEEM ice-core. A further 9 tephra deposits were used as an independent test of this timescale transfer. A similar approach was applied between NGRIP and GRIP by Seierstad et al., (in review) where 20 new tephra pairs support the synchronisation of these two records. The tephra deposits utilised for the aforementioned timescale transfer processes are components of the overall framework for Greenland presented here. 
Methods

103

104

Sampling was undertaken on four deep Greenland ice-cores: NGRIP, NEEM, GRIP and DYE-3 (Figure 1). Observations made by Davies et al., (2008; 2010), Abbott et al., (2012) and Coulter et al., (2012) have shown that glass shard particles can be present in the ice without an associated sulphate peak. Therefore a more continuous sampling approach was employed to explore the volcanic record preserved only in cryptotephra form. Sampling was based on the following criteria:

1. Ice spanning rapid climatic transitions (particularly the warming transitions);

2. The likely position of widespread volcanic events yet to be located in the Greenland ice, such as the Campanian Ignimbrite eruption of the Campi Flegrei, dated to $39.28 \pm$ $0.11 \mathrm{ka}$ (de Vivo et al., 2001) and the Dawson tephra deposit from the Aleutian Arc Alaska Peninsula region of southwestern Alaska, dated to 30,433-30,014 cal yrs BP (Demuro et al., 2008);

3. For the NEEM ice core, the likely positions of selected tephra deposits previously identified in the NGRIP ice core by Davies et al., $(2008,2010)$ and the presence of glass shards in low-resolution $(1.1 \mathrm{~m})$ water samples collected from the NEEM continuous flow analysis (CFA) set-up.

This amounted to $113.3 \mathrm{~m}$ of NGRIP ice between $1823.80 \mathrm{~m}$ and $2178.00 \mathrm{~m}$ and $97.35 \mathrm{~m}$ between $1617.55 \mathrm{~m}$ and $1845.25 \mathrm{~m}$ in the NEEM ice core. The GRIP and DYE-3 cores were largely sampled to investigate the second criterion and therefore the ice sampled is limited to $97.9 \mathrm{~m}$ between $1998.15 \mathrm{~m}$ and $2231.35 \mathrm{~m}$ in the GRIP ice core and $34.10 \mathrm{~m}$ between 1865.60 and $1914.00 \mathrm{~m}$ in the DYE-3 ice core (Table 1). 
125 Ice cross-sections of $2 \mathrm{~cm}^{2}$ were removed from the edge of $55 \mathrm{~cm}$ long archive core sections stored at the University of Copenhagen. These $55 \mathrm{~cm}$ long samples were then cut into $3 \mathrm{sub}-$ samples of either 15 or $20 \mathrm{~cm}$ length for NGRIP, NEEM and GRIP. As the DYE-3 record is a lower temporal resolution at these depths, the DYE-3 samples were cut into 6 sub-samples of 10 or $5 \mathrm{~cm}$ length. These individual ice samples were melted at room temperature and centrifuged to concentrate any particulate matter. The particulate material was dried onto frosted microscope slides and embedded in epoxy resin. Samples were then examined for tephra shards using optical light microscopy. Any samples containing 5 or more glass shards were subsequently prepared for geochemical analysis. Thin sections of the tephra shards were produced by grinding and polishing the samples using silicon carbide paper and 9,6 and $1 \mu \mathrm{m}$ diamond suspension.

Electron-probe microanalysis (EPMA) of the identified glass shards took place during seven analytical periods at the Tephra Analytical Unit at the University of Edinburgh. A Cameca SX-100 electron microprobe with five vertical wavelength dispersive spectrometers was employed to analyse oxide values for 10 major and minor elements within individual glass shards. Both a 3 and $5 \mu \mathrm{m}$ beam diameter were used, according to the grain-size of the samples, and the operating conditions followed those outlined by Hayward (2012). Secondary standard analyses of Lipari Obsidian and BCR2G basalt were run at the beginning and end of each day, as well as at regular intervals between samples. The full geochemical results, including the operating conditions, beam diameter employed for each sample and standard data are provided in the Supplementary data.

In all cases, the tephra deposits identified have been given a unique label. This is derived from the name of the ice core and the basal depth of the sample containing the glass shards. 
For example, the label for the tephra layer in NGRIP sample $2065.45-2065.65 \mathrm{~m}$ will be NGRIP $2065.65 \mathrm{~m}$.

152

153 The tephra horizons can be assigned ages using the annual-layer counted chronology, the 154 GICC05 timescale for the NGRIP core (see; Andersen et al., 2006; Svensson et al., 2006, Svensson et al., 2008 for details of the layer counting). This timescale has been transferred to the NEEM and GRIP ice cores using a series of reference horizons (chemo-stratigraphy as well as tephra horizons), which allows GICC05 ages to be assigned to any tephra horizons identified within NEEM and GRIP (Rasmussen et al., 2013; Seierstad et al., in review). The GICC05 timescale has errors on the ages based on the concept of maximum counting errors (MCE), which can be viewed as $2 \sigma$ errors (see Rasmussen et al., 2006; Andersen et al., 2006; Svensson et al 2008). There is no GICC05 chronology for the DYE-3 sections studied here, therefore ages for tephra deposits found in that record are approximations and are inferred from their stratigraphic position and wiggle matching of the DYE-3 isotope record to the NGRIP isotope record. Correlation of tephra deposits between ice-cores may improve the precision of these ages.

The most likely volcanic source for each tephra deposit is suggested based on comparison to the best available published data. Due to the limited preservation of pre-Holocene deposits on Iceland, no proximal tephra records in the 25-45 ka time-interval are available for comparison (Haflidason et al 2000). Furthermore, distally-preserved tephra data-sets from Icelandic eruptions between 25 and $45 \mathrm{ka}$ are sparse and dominated by the Grimsvötn-sourced Faroe Marine Ash Zones described in Wastegård et al., (2006). The major producers of basaltic tephra during the Holocene are the Grimsvötn, Katla, Veidvötn-Bárdarbunga, Kverkfjöll and

174 Vestmannaeyjar systems (Larsen and Eiríksson, 2007), whilst the central volcanoes that have 
predominantly erupted silicic tephra during the Holocene are Hekla, Askja, Öræfajökull, Torfajökull, Snæfellsjökull, Eyjafjallajökull and Katla. We employ Holocene glass data-sets (Larsen et al., 2002, Meara, 2012; Óladottir et al., 2008, 2011a and b) and whole rock data (Jakobsson, 1979; 2008) from Icelandic samples/records for these most productive source volcanoes. These data-sets are also supplemented by distal tephra glass occurrences from both Holocene and last glacial eruptions (Boygle, 1994; Hunt et al., 1995; Dugmore and Newton, 1998; Haflidason et al., 2000 and references within, Davies et al., 2001 ; Wastegård et al., 2001, 2006 ; Andrews et al., 2002; Mortensen et al., 2005).

Correlation of tephra layers between ice-cores is initially based upon major element geochemistry. However, where major element geochemistry alone is not distinctive, the Greenland event stratigraphy, which is based on high-resolution Greenland $\delta^{18} \mathrm{O}$ and calcium records (Rasmussen et al., in review), can be used to discriminate between tephra with similar geochemical signatures positioned in different climate periods (i.e. different interstadials and stadials). In cases where multiple eruptions with similar geochemical composition are located in very similar stratigraphic positions, a potential tephra correlation can be tested according to whether it is consistent with the depth-depth relationship from the chemo-stratigraphic tiepoints between the cores which assumes that the ratio of the layer thickness is slowly varying (Seierstad et al., in review, Rasmussen et al., 2013).

Tephra correlations identified between NGRIP and NEEM and NGRIP and GRIP are presented in Rasmussen et al., (2013) and Seierstad et al., (in review) respectively. These individual tephra deposits are described for the first time and are present in the descriptive biplots of Figure $3-7$. However, details of the correlations are not dealt with here. The full geochemical data for these deposits are outlined for the first time in the supplementary 
information. Similarly, tephra geochemical data from Davies et al., (2010) and Bourne et al., (2013) are not plotted in biplots alongside the new data here and the full data-sets are available in the original publications. However, all previously published tephra deposits from Davies et al., (2010), Bourne et al., (2013), Rasmussen et al., (2013), Seierstad et al (submitted) are included in the overall tephrochronological framework tabulated in Tables 2 and 3.

\section{Results}

Within our time-window, 42 cryptotephra deposits were identified in NGRIP, of which 39 are basaltic in composition. Twenty tephra deposits were identified in NEEM, of which 17 exhibit a basaltic affinity and one is a visible layer. Twenty-two cryptotephra deposits were identified in GRIP all of which are basaltic in composition and 15 cryptotephra deposits were identified in DYE-3 with 14 of basaltic composition (Figure 2). A number of these deposits fall close to rapid transitions on the $\delta^{18} \mathrm{O}$ records (Figure 2).

For clarity, the results from all four ice cores will be considered in four time periods (Figure 2). These periods are determined by the areas of GRIP and DYE-3 that were sampled and consist of: Period 1 from 25 ka to 32 ka b2k encompassing GS-3 to GS-5.2, period 2 from 32 ka to $37 \mathrm{ka} \mathrm{b2k}$ encompassing GI-5.2 to GS-8, period 3 from $37 \mathrm{ka}$ to $41 \mathrm{ka} \mathrm{b} 2 \mathrm{k}$ encompassing GI-8 to GS-10 and period 4 from 41 ka to $46 \mathrm{ka}$ b2k encompassing, GI-10 to GI-12 (Table 1). The number of tephra layers, amount of ice sampled and average grain size in each time period is shown in Table 1. These results include six NGRIP tephra deposits in Period 1 which were previously published by Davies et al., (2010) and twenty tephra deposits in Period 3 (5 in NEEM and 15 in NGRIP) that were previously published by Bourne et al., (2013) (Table 1). 
Period 1 - 25-32 ka b2k, GS-3 to GS-5.2

228

The ice sampled in this time period consisted of $55.55 \mathrm{~m}$ from NGRIP (46\% of total ice from the period), $30.8 \mathrm{~m}$ from NEEM (44\% of total ice), $52.8 \mathrm{~m}$ from GRIP (48 \% of total ice) and $15.4 \mathrm{~m}$ from DYE-3 (Table 1). A total of 37 tephra layers are present within this time period, 8 from NGRIP, 9 from NEEM, 12 from GRIP and 8 from DYE-3. Within this time period six tephra deposits have been previously identified in NGRIP (Davies et al., 2008, 2010) and the stratigraphic positions, ages, chemical compositions and source volcanoes of both new and published tephra layers are shown in Table 2 .

Average grain-size for these tephra layers varies between cores with larger shards present in DYE-3 with an average grain size of $57.3 \mu \mathrm{m}$ (Table 1). In contrast, the average grain size of the GRIP tephra deposits is $36.8 \mu \mathrm{m}, 33.5 \mu \mathrm{m}$ for NGRIP deposits and $27.1 \mu \mathrm{m}$ for the NEEM deposits (Table 1).

Within this time period 35 of the deposits are basaltic in composition with just two of rhyolitic composition, NGRIP $1888.10 \mathrm{~m}$ and NEEM $1636.45 \mathrm{~m}$ (Figure 3A). With only one glass shard analysed from NEEM $1636.45 \mathrm{~m}$ it is difficult to pinpoint a source volcano (Figure 4). NGRIP $1888.10 \mathrm{~m}$, however, shows closest affinity to products from Hekla (Figure 4). Several of the basaltic deposits exhibit similar geochemical signatures (Figure 3A, Table 2). The majority of the glass shard analyses for NGRIP, NEEM and GRIP tephra deposits reveal homogenous and tightly-clustered populations. However, one or two outlying analyses are observed in some of the deposits e.g. GRIP 2002.20 m, GRIP 2070.20 m, and NEEM 1669.25 $\mathrm{m}$ (Figure 3C and D). In contrast, the 8 deposits present in DYE-3 exhibit 
marked heterogeneous geochemical signatures. For instance $\mathrm{SiO}_{2}$ and $\mathrm{FeO} / \mathrm{TiO}_{2}$ values for shards from DYE-3 1865.80 m vary between 46.70 and $59.62 \%$ wt and 3.19 and $7.00 \%$ wt respectively (Figure 3A and E). As such glass shards from this one sample fall within geochemical fields for Katla, Grimsvötn and Veidivötn (Figure 3E). This heterogeneity is common to all DYE-3 tephra deposits and therefore it is not possible to assign these deposits to one source volcano. The only tephra deposit that does exhibit some homogeneity is DYE$31869.15 \mathrm{~m}$, which can be tentatively assigned to the Grimsvötn volcanic source.

Tephra deposits of transitional alkali and tholeiitic basalt composition dominate this period with 12 deposits clustering within the Katla field and 13 deposits falling within the Kverkfjöll/Grimsvötn fields (Figures 3B, C and D). Two distinct tholeiitic tephra deposits are separated from the Katla and Kverkfjöll geochemical clusters observed in Figure 3B and C. NGRIP $1894.05 \mathrm{~m}$ and NEEM $1636.65 \mathrm{~m}$ are geochemically distinct from the other basaltic horizons with an $\mathrm{FeO} / \mathrm{TiO}_{2}$ ratio of $>6$ (Figure 3B). Although Veidivötn is a likely source for NGRIP $1894.05 \mathrm{~m}$, the source for NEEM $1636.65 \mathrm{~m}$ is uncertain with $\mathrm{SiO}_{2}$ values ranging between 49.22 and $52.17 \%$ wt and an $\mathrm{FeO} / \mathrm{TiO}_{2}$ ratio of between 7.66 and $8.69 \%$ wt (Figure 3B and C).

It is very difficult to separate the Katla tephra deposits based on geochemical results alone (Figure 3F). Small variations, however, can be observed between some of the tephra deposits e.g. NEEM $1669.25 \mathrm{~m}$ reveal $\mathrm{CaO}$ values of $11-11.7 \mathrm{wt} \%$ whereas the $\mathrm{CaO}$ values for GRIP 2049.50 $\mathrm{m}$ and NEEM $1656.50 \mathrm{~m}$ range between 9.5 and $11 \mathrm{wt} \%$. There is however, a great deal of overlap between these Katla deposits and difficulties may arise in using these for correlating to tephra deposits in other sequences when only one deposit is present. The stratigraphic position of these Katla deposits should, therefore, be used in tandem with the 
geochemical results to avoid any potential mis-correlations. For instance, NGRIP $1882.10 \mathrm{~m}$ and NEEM $1648.90 \mathrm{~m}$ have been correlated according to their geochemical signatures and their stratigraphic position within GS-4 by Rasmussen et al., (2013) (Table 2). These are the only transitional alkali basalts deposited during GS-4 and, thus, can be discriminated from the other layers shown in Figure 3B and E. Likewise, GRIP $2070.20 \mathrm{~m}$ is the only tephra of Katla origin deposited during GI-5.1 and NGRIP 1929.95 m, NEEM $1677.60 \mathrm{~m}$ and GRIP $2079.40 \mathrm{~m}$ all relate to the same volcanic event during GS-5.2 and are, thus, stratigraphically distinct. However three layers are located in GS-3 (NEEM 1626.15 m, NGRIP $1855.80 \mathrm{~m}$ and NGRIP $1861.55 \mathrm{~m}$ ) with a further three tephra deposits in GS-5.1 which cannot be discriminated from one another using geochemistry or stratigraphy.

Tephra deposits originating from Kverkfjöll also exhibit similar geochemical signatures but can be discriminated based on very small differences in their $\mathrm{TiO}_{2}$ values (Figure $3 \mathrm{G}$ ). For example GRIP $2002.20 \mathrm{~m}$ has $\mathrm{TiO}_{2}$ values of 3.6-3.7\% whereas GRIP $2064.35 \mathrm{~m}$ has $\mathrm{TiO}_{2}$ values of 3.2-3.3\%. Some layers for example NEEM $1664.95 \mathrm{~m}$ and NEEM $1671.85 \mathrm{~m}$ cannot be discriminated using geochemical signatures (Figure 3G), however their stratigraphic position (GS-5.1 and GI-5.1 respectively) does allow for discrimination between these layers (Table 2).

Period 2 -32-38 ka b2k, GI-5.2 to GS-8

The ice sampled in this period consisted of $50.05 \mathrm{~m}$ from NGRIP (40\% of total ice in this period) and $26.4 \mathrm{~m}$ from NEEM (37\% of total ice) (Table 1). Nine tephra layers are present in this time period, 5 from NGRIP and 4 from NEEM (Table 2, Figure 4 and 5). GRIP and DYE-3 were not sampled during this time period. The NGRIP grain size average is $30.6 \mu \mathrm{m}$, 
with an average maximum grain size of $51.0 \mu \mathrm{m}$. The NEEM average grain size is $18.6 \mu \mathrm{m}$, with an average maximum shard size of $35 \mu \mathrm{m}$ (Table 2).

Seven of the nine deposits in this time period are basaltic in composition, with two transitional alkali deposits and four tholeiitic deposits (Figure 5A). NGRIP $1954.70 \mathrm{~m}$, NGRIP $1952.15 \mathrm{~m}$ and NEEM $1690.35 \mathrm{~m}$ originate from Katla, Iceland (Figure 5B-D). NGRIP $1952.15 \mathrm{~m}$ and NEEM $1690.35 \mathrm{~m}$ exhibit overlapping geochemical signatures and are believed to relate to the same volcanic event (Rasmussen et al., 2013) (Figure 5). Despite the Katla origin, NGRIP $1954.70 \mathrm{~m}$ is distinctive from NGRIP $1952.15 \mathrm{~m}$ and NEEM $1690.35 \mathrm{~m}$ (apart from 2 outliers) due to its lower $\mathrm{SiO}_{2}$ and higher $\mathrm{TiO}_{2}$ values (Figure 5B-D). The remaining four layers originate from Kverkfjöll (Figure 5B-D) and can be separated into two groups based on their $\mathrm{Al}_{2} \mathrm{O}_{3}$ and $\mathrm{TiO}_{2}$ values (Figure 5B). Moreover, these tephra deposits can also be distinguished based on their stratigraphic positions as NGRIP $1950.50 \mathrm{~m}$ and NEEM $1689.25 \mathrm{~m}$ fell during GI-5.2 and NGRIP $1973.16 \mathrm{~m}$ and NEEM $1702.40 \mathrm{~m}$ were deposited during GI-6. NGRIP $1950.50 \mathrm{~m}$ and NEEM $1689.25 \mathrm{~m}$ have lower $\mathrm{TiO}_{2}$ and higher $\mathrm{Al}_{2} \mathrm{O}_{3}$ values (Figure $5 \mathrm{C}$ ) and were assigned to the same volcanic event by Rasmussen et al., (2013). NEEM 1693.45 m and NGRIP 2009.15m are dacitic to rhyolitic in composition and show geochemical affinity to Hekla products (Figures 4 and 5a).

\section{Period 3 - 37-41 ka b2k, GI-8 to GI-9}

Within this time period $45.65 \mathrm{~m}$ of NGRIP ice (91\% of the available ice-core representing this interval), $26.4 \mathrm{~m}$ of NEEM ice ( $86 \%$ of total ice), $45.10 \mathrm{~m}$ of GRIP ice (100\% of total) and $18.70 \mathrm{~m}$ of DYE-3 ice (100\% of total) was sampled and 19 previously unreported tephra layers were identified (Table 1). Of these, two are from NEEM, 10 from GRIP and 7 from DYE-3 (Table 2, Figure 4 and 6). In addition to these layers another 20 tephra deposits in this 
time period were reported by Bourne et al., (2013) and are included in the overall framework in Table 2 but are not plotted in Figure 6. Of these twenty tephras, 15 were identified in NGRIP and 5 in NEEM and the geochemical results reveal that they all fall within the compositional envelope of the marine Faroe Marine Ash Zone III deposit (Bourne et al., 2013).

DYE-3 again has the largest average grain size in this time period (54.6 $\mu \mathrm{m}$, Table 3) compared to the GRIP average of $45.6 \mu \mathrm{m}$, the NGRIP deposits of Bourne et al., (2013) have an average grain size of $29.3 \mu \mathrm{m}$ and all the NEEM tephras deposits have an average grain size of $25.0 \mu \mathrm{m}$.

Of the new deposits reported here, 17 are basaltic in composition (Figure 6A), with 16 originating from Grimsvötn and one, GRIP 2213.05 m, originating from Katla (Figure 6 BC). DYE-3 1895.55 m, DYE-3 1901.80 m, DYE-3 1904.10 m, and DYE-3 $1904.15 \mathrm{~m}$ are more homogenous than those identified in Period 1, and plot within the Grimsvötn field (Figure 6A-C). However DYE-3 $1900.80 \mathrm{~m}$ and DYE-3 $1912.35 \mathrm{~m}$ still show geochemical heterogeneity (Figure 6B and C) but all show geochemical affinity to Grimsvötn. NEEM $1784.46 \mathrm{~m}$ has a mafic composition, falling in the basaltic andesite composition of the TAS plot (Figure 6A). The only rhyolitic tephra from this period is DYE-3 $1898.65 \mathrm{~m}$ (Figure 6A) and based on $\mathrm{TiO}_{2}$ and $\mathrm{FeO}$ values is thought to originate from Hekla, as is NEEM 1784.46 m (Figure 4). The 17 eruptions from Grimsvötn are geochemically very similar, however small differences in the $\mathrm{TiO}_{2}$ values do allow these eruptions to be split into three main groupings (Figure 6C) but with only limited stratigraphical separation. Within the highest $\mathrm{TiO}_{2}$ grouping (3.0-3.5 \%wt) both GRIP $2227.15 \mathrm{~m}$ and GRIP $2227.90 \mathrm{~m}$ are located in GS10, and thus stratigraphic position cannot be used as an additional discriminatory tool for 
these tephra deposits (Figure 6C, Table 2). Slightly lower $\mathrm{TiO}_{2}$ values $(2.75-3.00 \% \mathrm{wt}$ ) for GRIP 2195.45 m, GRIP 2197.25 m, DYE-3 1895.55 m, DYE-3 1901.80 m, DYE-3 1904.10 m and DYE-3 $1904.15 \mathrm{~m}$, give these a somewhat distinctive character. Both GRIP layers are positioned in GI-8c, meaning stratigraphic discrimination is not possible (Table 2, Figure 6C). Finally in the lowest $\mathrm{TiO}_{2}$ group (2.00-2.75 \%wt) NEEM $1747.10 \mathrm{~m}$ and GRIP 2190.65 $\mathrm{m}$ are located in GI-8c (Table 2), and GRIP 2200.75 m, GRIP $2201.50 \mathrm{~m}$, and GRIP 2207.00 $\mathrm{m}$ are located in GS-9 (Table 2), meaning some limited additional discrimination based on stratigraphy is possible. Thus, small geochemical variations allow the discrimination of tephra deposits within these three groupings, but using their stratigraphic positions as an added discrimination tool in this particular context is limited.

This time period was sampled intensively to detect whether the Campanian Ignimbrite (CI) tephra layer was present in a Greenland ice-core. This is one of the largest eruptions of the Late Quaternary in the Mediterranean region (Pyle et al., 2006) and dated to $39.28 \pm 0.11 \mathrm{ka}$ (de Vivo et al., 2001). Tephra from this eruption was not present in NGRIP or NEEM (Bourne et al., 2013) and no tephra layers with trachy-phonolitic geochemistry, typical of the CI were identified in GRIP or DYE-3 either.

\section{Period 4 - 41-46 ka b2k, GS-10 to GS-12}

Within this time period $30.25 \mathrm{~m}$ of NGRIP ice (34 \% of available ice) and $8.8 \mathrm{~m}$ of NEEM ice (18\% of total ice) was sampled (Table 1), no ice was sampled from GRIP or DYE-3. Eight tephra deposits are present in this time period, all of them from NGRIP, as only a small amount of NEEM ice was sampled. The stratigraphic positions, ages, chemical compositions and source volcanoes of the tephra layers are shown in Figure 7 and are summarised in Table 
24.1 $\mu \mathrm{m}$, which is consistent with the results from this core location in other time periods. Each of the deposits in this time period are tholeiitic basaltic in composition and all originate from the Grimsvötn volcano, although NGRIP $2163.35 \mathrm{~m}$ also contains a sub population of dacitic shards that appear to originate from Hekla (Figure 4), suggesting two closely spaced eruptions that are not stratigraphically resolved in the $20 \mathrm{~cm}$ sample. All of the Grimsvötn deposits, are geochemically very similar, however they can be split into two groups based on the $\mathrm{CaO}$ composition with NGRIP $2150.90 \mathrm{~m}$, NGRIP $2162.05 \mathrm{~m}$ and NGRIP $2185.70 \mathrm{~m}$ forming one group with lower $\mathrm{CaO}$ and $\mathrm{TiO}_{2}$ values (Figure 7B and $\mathrm{C}$ ). These 3 deposits can also be separated stratigraphically and fell during GI-11 (NGRIP 2150.90 m), GS-12 (NGRIP $2162.05 \mathrm{~m}$ ) and GI-12c (NGRIP 2185.70 m) (Figure 2, Table 2). NGRIP 2162.60 m, NGRIP 2163.35 m, NGRIP 2164.10 $\mathrm{m}$ and NGRIP $2188.25 \mathrm{~m}$ form the second group with a lower $\mathrm{FeO} / \mathrm{TiO}_{2}$ ratio and higher $\mathrm{CaO}$ values (Figure 7C and D). Stratigraphically NGRIP 2188.25 $\mathrm{m}$ can be distinguished from the other 3 layers, as it is positioned in GI-12c, as opposed to GS-12. NGRIP $2186.80 \mathrm{~m}$ is the most geochemically distinct layer in this time period with lower $\mathrm{FeO}$ and higher $\mathrm{CaO}$ values and can, thus, be easily discriminated from the younger NGRIP tephras in this period (Figure 7D).

\section{Discussion}

An investigation of tephra deposits preserved within 4 different Greenland ice-cores provides a detailed record of Icelandic volcanism over the glacial period between 25 and $45 \mathrm{ka}$ b2k (Table 2). Together with the previously published tephra deposits in Davies et al., (2008, 2010) and Bourne et al., (2013), 99 tephra layers are identified during this interval. This framework represents a significant advancement in our understanding of the Icelandic volcanic history and is an important first step towards widening the use of tephra horizons for 
the synchronisation of the ice-cores with other palaeoclimatic archives. Some tephra deposits within this framework will be more valuable than others as marker horizons, but a detailed history of volcanic events is important to preclude any potential mis-correlations. When assessing the potential of individual tephra deposits for correlation purposes, the most valuable deposits will be: i) robustly characterised and geochemically distinct, ii) widespread in extent and iii) well-dated and deposited close to an event of rapid change (Davies et al., 2012).

\section{Assessing the value of individual tephra deposits: geochemical characterisation}

All of the layers identified here have been robustly geochemically characterised but several deposits exhibit similar geochemical signatures. Their use as time-parallel marker horizons is subject to careful scrutiny of geochemical results and, where possible, the stratigraphic position of the tephra in question. In particular, ninety-four of the layers are basaltic in composition with 43 originating from Grimsvötn, 17 deposits are from Kverkfjöll, which has previously been suggested to form a single volcanic system with Grimsvötn (Grönvold and Jóhannesson, 1984), and 19 are from Katla. Whilst several of these layers are geochemically similar, 70 of the layers can be discriminated based either on small geochemical differences or their stratigraphic position (provided this can be adequately resolved in other sequences).

Often, however, the small geochemical differences are between 0.2 and $0.5 \mathrm{wt} \%$ and, thus, it is essential that geochemical analysis of any potential correlatives is bracketed by analysis of international secondary standards.

This large number of basaltic horizons is in contrast to the number identified in the same time-interval within the European INTIMATE tephra framework, where only 2 basaltic horizons are identified (Blockley et al., 2012; Davies et al., 2012). This difference in the 
number of basaltic tephra layers found in Greenland and in terrestrial European records could

425 be due to the preferential dispersal of basaltic eruptions from Iceland towards Greenland or could reflect the fact that routine density separation techniques employed to detect cryptotephra in terrestrial records does not allow detection of basaltic material (Turney, 1998; Blockley et al., 2005; Larsen and Eiriksson., 2007). This situation may well change with the wider application of a magnetic separation technique for the isolation of glass shards of basaltic composition from sedimentary deposits (e.g. Mackie et al., 2002; Griggs et al., in press).

Assessing the value of individual tephra deposits: geographical extent

As yet, the geographical extent of these tephra deposits outside of Greenland is currently unknown, but by investigating the tephra record within the different ice-cores, we can reconstruct the extent of ash deposition over the ice sheet. NGRIP and NEEM correlations and NGRIP and GRIP correlations have been outlined previously by Rasmussen et al., (2013) and Seierstad et al., (in review), respectively (Table 2, Figure 8). We advance this work by highlighting 11 new correlations here giving particular attention to those tephras that can be traced between more than 2 ice-cores. A summary of all ice-core correlations, both new and published, is presented in Table 3. Statistical analyses (similarity coefficient and statistical distance) support these correlations and none of the statistical distances exceed the critical value, therefore no correlations are statistically different (Table 3).

Within Period 1, major element results indicate that the Katla-sourced deposit found within NGRIP 1895.24 m and NEEM 1656.50 m by Rasmussen et al., (2013) can also be extended to GRIP 2049.50 m (Figure 9A). Secondly GRIP $2060.85 \mathrm{~m}$ can be correlated to both NGRIP 1908.70 m and NEEM 1664.95 m, which were themselves correlated by Rasmussen et al., 
449 (2013) (Figure 9A). Finally, GRIP $2079.40 \mathrm{~m}$ can be correlated to NEEM $1677.60 \mathrm{~m}$ which 450 has already been correlated to NGRIP $1929.95 \mathrm{~m}$ by Seierstad et al., (in review) (Figure 9A). In Period 2, NGRIP $1973.16 \mathrm{~m}$ and NEEM $1702.45 \mathrm{~m}$ can be correlated for the first time (Figure 9B), their ages of 33,686 \pm 1207 yrs b2k and 33,692 \pm 1208 yrs b2k (Table 2) support this correlation. This correlation also provides a further independent test for the volcanic matching method used to transfer the GICC05 timescale to NEEM.

455

456 here and the NEEM data published in Bourne et al., (2013). The GRIP to NGRIP correlations are considered by Seierstad et al., (in review). GRIP $2195.45 \mathrm{~m}$ correlates to NEEM $1755.60 \mathrm{~m}$, GRIP $2197.45 \mathrm{~m}$ to NEEM $1757.10 \mathrm{~m}$, GRIP $2201.50 \mathrm{~m}$ to NEEM 1759.85 m, GRIP $2207.00 \mathrm{~m}$ to NEEM $1764.25 \mathrm{~m}$ and finally GRIP $2227.15 \mathrm{~m}$ to NEEM 1780.20 m (Figure 9c). Each tephra correlation has a similarity coefficient greater than 0.97 and the statistical distance does not exceed the critical value (Table 3), supporting the geochemical correlations (Figure 9C). Correlations to other GRIP layers in this period e.g. GRIP $2200.75 \mathrm{~m}$ and GRIP $2202.40 \mathrm{~m}$ can be excluded based on their stratigraphic position (Figures 2 and 8). Whilst the DYE-3 tephra layers appear to correlate with some of the GRIP layers (Figure 6), it is clear from their $\mathrm{FeO} / \mathrm{MgO}$ ratios that DYE-3 $1901.80 \mathrm{~m}$, DYE-3 1904.10 $\mathrm{m}$ and DYE-3 $1940.15 \mathrm{~m}$ are offset from GRIP $2195.45 \mathrm{~m}$ and GRIP $2197.25 \mathrm{~m}$ (Figure 9C). Therefore, whilst the DYE-3 layers in this time period reveal more geochemically homogenous populations than in period 1, they do not correlate with layers in the other ice-cores.

472 The correlation of GRIP $2197.45 \mathrm{~m}$ to NEEM $1757.10 \mathrm{~m}$ also implies a correlation to NGRIP $4732066.95 \mathrm{~m}$ as the NEEM and NGRIP layer were correlated by Rasmussen et al., (2013). This 
474 is supported by the geochemical data (Figure 9C, black triangles), however, the correlation of

475 NGRIP $2066.95 \mathrm{~m}$ and GRIP $2197.45 \mathrm{~m}$ is stratigraphically inconsistent with the recent synchronisation of the NGRIP and the GRIP cores based on chemo-stratigraphic records

477 (Seierstad et al. submitted). According to the chemo-stratigraphic matching the two tephra 478 layers are separated by 5 to 13 years (according to the actual stratigraphic position of the 479 tephra deposit within the $15 \mathrm{~cm}$ ice sample) (Seierstad et al., in review). Thus, the geochemical signatures support a tephra correlation, but the inconsistencies with the chemostratigraphic matching prevents a firm correlation (dashed red line, Figure 8).

With the new tephra correlations outlined here, 8 tephra horizons are common to GRIP, NGRIP and NEEM (Figure 8). A further four correlations are present between NGRIP and NEEM (green lines) and one additional correlation links NGRIP and GRIP (orange line) (Figure 8). The layers that only correlate between NGRIP and NEEM are found in period 2 and late in period 1, where the GRIP core was not sampled, indicating that with further targeted sampling of GRIP more correlations between all three cores may be identified. Single age estimates for these correlating tephra deposits are shown in Figure 8. These ages represent the basal age of the NGRIP sample, as the glacial part of the GICC05 chronology was based on NGRIP annual layer counting. If these layers are traced beyond Greenland then the ages presented in Figure 8 represent the age of the tephra deposit. No correlations were possible with the DYE-3 deposits due to their geochemical heterogeneity (especially in period 1) and geochemical offsets with period 3 deposits (Figures 3 and 9C). Glass shards from the same samples in DYE-3 show affinities to Katla, Grimsvötn and Veidivötn (Figure 3E). Many deposits are found within consecutive samples and the heterogeneous geochemical signatures suggest mixing of different tephra deposits. It is possible, that the 
deposits from individual eruptions as seen in the other cores. Secondly, Ram and Gayley

500 (1991) discuss whether the aggregates from the $\mathrm{Z} 2$ eruption (which is spread over $78 \mathrm{~cm}$ in

501

502

503

504

505

506

507

508

509

510

511

512

513

514

515

516

517

518

519

520

521

522

523

DYE-3) were caused by melt and refreeze, which could also be the cause of the geochemical heterogeneity observed here. Alternatively, as DYE-3 is the most southerly ice-core (Figure 1) it is possible that storms from Iceland could redeposit tephra on the ice-sheet surface (Arnalds et al., 2013; Prospero et al., 2012).

The deposits that correlate between GRIP, NGRIP and NEEM suggest a northerly dispersal of ash from Iceland, and they represent the most widespread deposits identified to date (Figure 8). The decrease in tephra grain size with increasing northerly latitude supports this direct transport route in a north westerly direction from Iceland to the Greenland core sites (Figure 10). This decrease appears to be a consequence of increasing distance from Iceland, which holds true when considering the distance of the ice-cores from Katla (Figure 10A), however GRIP is actually closer to Grimsvötn (the most common source of tephra layers here) than DYE-3 (Figure 10B). DYE-3 is at a lower altitude (2480 m above sea level (asl), than GRIP (3230 m asl) (Vinther et al., 2006) (Figure 1) suggesting that ash travelling to the GRIP drill site still has further to travel than that reaching DYE-3. The length of a typical air mass trajectory from Iceland to the drill sites may be the cause of the grain size decrease. This is very much dependent on the pathway of cyclones over the North Atlantic as retrograde transport relative to the overall westerly flow is required. On the whole, the decreasing grain-size trend with increasing latitude suggests ash is transported directly to the core sites from source. Whether or not these deposits are widespread beyond Greenland remains to be seen, and will require high-resolution investigations of sequences in the North Atlantic region and north and west of Greenland (if available). Until then, it is unknown whether volcanic ash from these eruptions was also dispersed eastwards towards Europe. 
Assessing the value of individual tephra deposits: tephra constraints on rapid climate events

526

527

528

529

530

531

532

533

534

535

536

537

538

539

540

541

542

543

544

545

546

547

548

In order to optimise the application of tephrochronology to establish the phase relationships between different proxy records, the most valuable tephras are those that fall close to rapid climatic events. In this case a tephra layer is considered to fall close to a rapid climate event if its age is within 100 years of the age of the stratigraphic boundaries defined by Rasmussen et al., (in review). Of the most widespread deposits only two, NGRIP 2066.95/NEEM 1757.10 m/GRIP $2197.45 \mathrm{~m}$ (no. 11 on Figure 8) and NGRIP $2071.50 \mathrm{~m} / \mathrm{NEEM} 1759.85$ m/GRIP 2201.50 m (no. 12 on Figure 8), constrains a rapid climate event (GI-8c onset) evident in the NGRIP $\delta^{18} \mathrm{O}$ curve (Figure 11).

However, five deposits common to both NGRIP and NEEM were deposited during the warming and cooling transitions of GI-3, GI-4, GI 5.2 and GI-6 (Figure 11). Finally a further 5 tephra deposits present only in NGRIP, 3 deposits found only in NEEM and 4 found only in GRIP are also found on rapid warming or cooling transitions (Figure 11). Thus, 19 tephra deposits within this framework (but 28 tephras from different cores) constrain rapid climate events of interest within the Greenland ice cores. Despite their useful stratigraphic position, their potential value to link different records rest on their distinct geochemical composition relative to other tephras close in age. Of these 19 tephra deposits NEEM 1636.65 m, NGRIP $1861.55 \mathrm{~m}$ (Figure 12A), NGRIP $1882.50 \mathrm{~m}$, NGRIP $1888.10 \mathrm{~m}$ (Figure 12B), NGRIP 1950.50/NEEM 1689.25 m, NGRIP 1952.15 m/NEEM 1690.35 m (Figure 12D), NGRIP $1973.16 \mathrm{~m} / \mathrm{NEEM} 1702.45 \mathrm{~m}$, NGRIP $2009.15 \mathrm{~m}$ (Figure 12E), NGRIP $2100.65 \mathrm{~m}$ and NEEM $1784.46 \mathrm{~m}$ (Figure 12G) are all compositionally unique from the other layers that sit in similar stratigraphic positions to these key layers, making these the most useful layers for tracing into other archives. NGRIP $1882.10 \mathrm{~m} / \mathrm{NEEM} 1648.9 \mathrm{~m}$ cannot be chemically 
distinguished from NGRIP 1895.24 m/NEEM $1656.50 \mathrm{~m} / \mathrm{GRIP} 2-49.50 \mathrm{~m}$, however they fall in GS-4 and GS-5.1, respectively, so could be distinguished from one another if found in

551 other well-resolved archives. However, NGRIP1915.50 m/NGRIP1915.63 m/NEEM 1669.25 m, GRIP 2067.85 m, GRIP 2070.20 m, GRIP 2070.60 m, NEEM 1671.85 m, NGRIP2066.95 m/NEEM1757.10 m/GRIP2197.25 m, GRIP2200.75 m and NGRIP 2071.50 $\mathrm{m} / \mathrm{NEEM} 1759.85 \mathrm{~m} / \mathrm{GRIP} 2201.50 \mathrm{~m}$ are all geochemically indistinguishable from other tephra deposits within the same stratigraphic unit (Figure 12C and F) suggesting that robust correlations of these deposits to other sequences will be more challenging.

Therefore the 10 layers that fall close to rapid climate events and are geochemically distinctive (layers in bold italic, Figure 11) are the most useful layers for establishing the phase relationships between different proxy records. NGRIP2066.95 m/NEEM1757.10 m /GRIP2197.25 m, GRIP2200.75 m and NGRIP 2071.50 m/NEEM1759.85 m/GRIP2201.50 m (numbers 11 and 12 Figure 8) are valuable as they are widespread and fall on a rapid transition, however they are geochemically similar to other tephra layers of a similar age and therefore care is needed if these are correlated to other archives. Likewise the other widespread deposits that are found across Greenland (Figure 8) may also represent valuable isochrons for future correlations to other disparate sequences.

Chemical indicators of volcanism in ice-cores and their relationship to tephra deposits

569 Initial work on tephra deposits preserved in ice cores focussed on horizons that were visible 570 in the record or sections of ice where large sulphate spikes were present (Grönvold et al., 1995; Mortensen et al., 2005). However recent research has begun to question whether using

572 the sulphate record is a reliable method for locating tephra deposits (e.g. Coulter et al., 2012).

573 Our investigation of more than $400 \mathrm{~m}$ of ice allows a detailed insight into the imprint of 
574 volcanic aerosol fallout (especially sulphate) in the ice alongside the stratigraphic position of 575 volcanic glass shards. The position of tephra deposits are considered relative to the NGRIP 576 electrical conductivity measurements (ECM, Fig. 13 a) (Dahl-Jensen et al., 2002) and NGRIP 577 concentrations of sulphate, dust and calcium as well as the conductivity of the liquid phase 578 (Bigler, 2004) with a particular focus on the continuously sampled portion of ice spanning 579 GI-9, GS-9 and GI-8 (Figure 13b and c).

580 Isolating and detecting volcanic sulphate spikes above a fluctuating and climatically-driven background level is complex (Figure 13). Sulphate concentrations in ice cores have a complex origin, sea salt, mineral dust, biogenic $\mathrm{H}_{2} \mathrm{~S}_{\mathrm{SO}}$ and volcanism contribute to the sulphate concentrations observed and a volcanic eruption will often give rise to sulphate spikes with concentrations of 3 - 10 micro equivalent $/ \mathrm{kg}$ (6 - 20 micro moles/kg) (Steffensen, 1995). When climate variability is low (e.g. during the Holocene and interstadial periods) the background level of sulphate in the ice is around 1-2 micro-equivalent/kg and natural variability in sulphate concentration is also low (1-2 micro-equivalent/kg inter annually) (Figure 13A and B). During these warm episodes the large sulphate spikes often stand out above background signals and are clearly detectable (Figure 13B and Ci). However during GI-8, NGRIP $2065.65 \mathrm{~m}$ is the only tephra layer to coincide with one of these large sulphate peaks that are discernible from the background signal (Figure 13Ci). The oldest tephra in this interval (NGRIP $2066.95 \mathrm{~m}$ ) is accompanied by a small peak in sulphate of 200 ppbw and no discernible signal is evident for NGRIP $2064.55 \mathrm{~m}$ (younger tephra). Large sulphate spikes in this interval e.g. at $2067.36 \mathrm{~m}$ do not coincide with glass shard deposition.

On the other hand, during the cold stadials of the last glacial, the amount of continental dust and other impurities in the ice are 10-20 times higher (see Figure 13B), giving a slightly alkaline signal to the ice. Most of the sulphate present in the ice during these times is derived 
from $\mathrm{CaSO}_{4}$ resulting from increased calcium ions caused by increased dustiness, which reacts with the naturally occurring sulphate in the ice. The background levels of sulphate are about 5 times higher than in interstadials, as is the natural variability. As such the increased input of sulphate from a volcanic eruption is masked and is not always a useful indicator. Therefore during cold stadial periods elevated sulphate values due to increased dustiness or volcanism are difficult to be discerned (Steffensen, 1995; Svensson et al., 2013). During the cold stadial of GS-9, the four tephra deposits present coincide with a peak in sulphate and other chemical indicators (Figure 13Cii). However, the sulphate is no greater than the general background level, which suggests that, whilst there is a link between the tephra deposition and the sulphate record, this would not be diagnostic if considering the sulphate record alone.

Our results suggest that the relationship between tephra deposition and coeval volcanic aerosol fallout is complex and it is unclear whether or not it is solely controlled by prevailing climatic conditions, which supports similar findings reported in Davies et al., (in press). Tephra deposits do fall in association with increased levels of the chemical indicators but the records are so variable that it is difficult to know whether or not they are related to each other or whether it's just coincidental. Therefore it is recommended that future tephra sampling be guided by time periods of interest and not peaks in the chemical records.

\section{Conclusions}

A detailed Greenland ice-core tephrochronological framework for GS-3 to GI-12 $(25,000-$ 45,000 yrs b2k) has been outlined. This framework builds on the work of Davies et al., (2010) and Bourne et al., (2013) and includes 99 geochemically characterised tephra deposits identified within the NGRIP, NEEM, GRIP and DYE-3 ice-cores. An examination of the relationship between tephra shards and chemical composition of the ice shows that, whilst 
tephra deposits do occur with small peaks in sulphate, this is not a sufficient diagnostic to use as an indicator of the presence of tephra deposits.

This study improves our understanding of Icelandic volcanic history and is a crucial first step to facilitate the synchronisation of the Greenland ice-cores with other palaeoclimatic archives. In particular, fourteen tephra deposits are traced in at least 2 ice-cores (Figure 8) and their extensive nature adds value as potential isochrons. In addition, 19 tephra deposits constrain the rapid warming and cooling transitions that characterise this time period and 10 of these are geochemically distinct (Figures 11 and 12) also revealing their value as isochrons. Therefore tephra deposits outlined in both Figure 8 and 11 should be an important focus for tracing these cryptotephra deposits in distal and high sedimentation areas of the North Atlantic region, where some of the Greenland tephra layers may also be preserved.

Given the large number of basaltic tephra layers present in the Greenland ice-cores it would be particularly beneficial to employ extraction methods such as the magnetic separation technique that also allow the identification of basaltic cryptotephra deposits within mineralrich marine and terrestrial sediments (e.g. Griggs et al., in press). Once identified, potential correlatives to the tephra deposits described here also require robust geochemical characterisation for rigorous comparison to the ice-core tephra deposits, to ensure that they are correlated robustly.

\section{Acknowledgements}

This study forms part of the Tephra constraints on Rapid Climate Events (TRACE) project which aims to use tephra layers found in Greenland Ice Core and North Atlantic marine cores to consider the mechanisms of abrupt palaeoenvironmental change. The research leading to 

these results has received funding from the European Research Council under the European Union's Seventh Framework Programme (FP7/2007-2013) / ERC grant agreement $\mathrm{n}^{\circ}$ [259253]. It is a contribution to the NorthGRIP ice-core project, which is directed and organised by the Centre for Ice and Climate at the Niels Bohr Institute, University of Copenhagen. It is being supported by funding agencies in Denmark (SNF), Belgium (FNRSCFB), France (IFRTP and INSU/CNRS), Germany (AWI), Iceland (RannIs), Japan (MEXT), Sweden (SPRS), Switzerland (SNF) and the United States of America (NSF). This work is also a contribution to the North Greenland Eemian Ice Drilling project which is directed and organized by the Centre for Ice and Climate at the Niels Bohr Institute and US NSF, Office of Polar Programs. It is supported by funding agencies and institutions in Belgium (FNRS-CFB and FWO), Canada (NRCan/GSC), China (CAS), Denmark (FI), France (IPEV, CNRS/INSU, CEA and ANR), Germany (AWI), Iceland (RannIs), Japan (NIPR), South Korea (KOPRI), The Netherlands (NWO/ALW), Sweden (VR), Switzerland (SNF), the United Kingdom (NERC) and the USA (US NSF, Office of Polar Programs). AJB, SMD and PMA are financially supported by the European Research Council (TRACE project: 259253) and acknowledge the support of the Climate Change Consortium of Wales (C3W). EC was financially supported by STSM funding from EU-COST INTIMATE action (ES0907). We would like to thank Dr Chris Hayward for his assistance with the use of the electron microprobe at the Tephrochronology Analytical Unit, University of Edinburgh. Thanks also to Gareth James, Gwydion Jones, Kathryn Lacey, Rhian Meara, Adam Griggs, and Lars Berg Larsen for help with the ice-core sampling. Kathryn Lacey is also thanked for her assistance with the slide preparation. This paper contributes to the EU-COST INTIMATE action (ES0907) and to the INTREPID project (Enhancing tephrochronology as a global research tool through improved fingerprinting and correlation techniques and 
673

674

675

676

677

678

679

680

681

682

683

684

685

686

687

688

689

690

691

692

693

694

695

696

697

uncertainty modelling an INQUA INTAV-led project (International Focus Group on Tephrochronology and Volcanism, project no. 0907).

\section{Figure Captions}

Figure 1 - Location of NGRIP, NEEM, GRIP and DYE-3 ice cores relative to the Katla and Grimsvötn volcanoes. The altitude of each core site is also given.

Figure 2 - Stratigraphic position of tephra horizons identified within four different Greenland ice-cores. Each tephra deposit is represented by a red line and plotted against the oxygen isotope stratigraphy for each core. Also shown is the NGRIP $\delta^{18} \mathrm{O}$ curve plotted on the GICC05 timescale for 25-45 ka b2k (Andersen et al., 2006). The four time periods used to discuss the tephra deposits in the text are also shown. The Greenland event stratigraphy is shown alongside the oxygen isotope record with GI (interstadial) events shown according to Rasmussen et al. (in review).

Figure 3 Geochemical results for the new tephra deposits identified in period 1 (25-32 ka b2k) A) Total Alkalis vs. Silica diagram (Le Bas et al., 1986). $\mathrm{SiO}_{2}$ vs. FeO/TiO 2 biplots for the B) NGRIP deposits, C) NEEM deposits, D) GRIP deposits and E) DYE-3 deposits. Geochemical fields for Icelandic source volcanoes are based on data presented in Jakobsson (1979; 2008), Boygle (1994), Hunt et al. (1995), Dugmore and Newton (1998), Haflidason et al. (2000) and references within, Davies et al. (2001), Wastegård et al. (2001, 2006), Larsen et al. (2002), Andrews et al. (2002), Mortensen et al. (2005), Óladottir et al. (2008, 2011a and b). F) $\mathrm{FeO}$ vs. $\mathrm{CaO}$ biplot for the transitional alkali layers in GRIP, NGRIP and NEEM. G) $\mathrm{FeO} / \mathrm{MgO}$ vs. $\mathrm{TiO}_{2}$ for the tholeiitic layers in GRIP, NGRIP and NEEM. Data shown are 
normalised values. Error bars represent 2 standard deviations of replicate analyses of the BCR2G reference glass.

Figure 4 - Geochemical results for glass shard analyses from mafic and silicic deposits. Geochemical fields are adapted from Meara (2012). Data shown are normalised values. Error bars represent 2 standard deviations of replicate analyses of the Lipari Obsidian reference glass.

Figure 5 -- Major element biplots for all tephra deposits identified during period 2 (32-37 ka b2k). A) Total Alkalis vs. Silica diagram (Le Bas et al., 1986). B) $\mathrm{Al}_{2} \mathrm{O}_{3}$ vs. $\mathrm{TiO}_{2}$ biplot C) $\mathrm{K}_{2} \mathrm{O}$ vs. $\mathrm{TiO}_{2}$ biplot and $\left.\mathrm{D}\right) \mathrm{SiO}_{2}$ vs. $\mathrm{FeO} / \mathrm{TiO}_{2}$ biplot. Geochemical fields for Icelandic source volcanoes are based on data presented in Jakobsson (1979; 2008), Boygle (1994), Hunt et al. (1995), Dugmore and Newton (1998), Haflidason et al. (2000) and references within, Davies et al. (2001), Wastegård et al. (2001, 2006), Larsen et al. (2002), Andrews et al. (2002), Mortensen et al. (2005), Óladottir et al. (2008, 2011a and b). Data shown are normalised values. Error bars represent 2 standard deviations of replicate analyses of the BCR2G reference glass.

Figure 6 Major element biplots for all new tephra deposits identified during period 3 (37-41 ka b2k). A) Total Alkalis vs. Silica diagram (Le Bas et al., 1986). B) $\mathrm{SiO}_{2}$ vs. $\mathrm{FeO} / \mathrm{TiO}_{2}$ biplot. C) $\mathrm{Al}_{2} \mathrm{O}_{3}$ vs. $\mathrm{TiO}_{2}$ biplot with an inset to show variation within the Grimsvötn field. Geochemical fields for Icelandic source volcanoes are based on data presented in Jakobsson (1979; 2008), Boygle (1994), Hunt et al. (1995), Dugmore and Newton (1998), Haflidason et al. (2000) and references within, Davies et al. (2001), Wastegård et al. (2001, 2006), Larsen et al. (2002), Andrews et al. (2002), Mortensen et al. (2005), Óladottir et al. (2008, 2011a and 
b). Data shown are normalised values. Error bars represent 2 standard deviations of replicate analyses of the BCR2G reference glass.

Figure 7 Major element biplots for all tephra deposits identified during period 4 (41-46ka b2k) A) Total Alkalis vs. Silica diagram (Le Bas et al., 1986) B) $\mathrm{Al}_{2} \mathrm{O}_{3}$ vs. $\mathrm{TiO}_{2}$ biplot, C) $\mathrm{SiO}_{2}$ vs. $\mathrm{FeO} / \mathrm{TiO}_{2}$ biplot and $\left.\mathrm{D}\right) \mathrm{CaO}$ vs. FeO. Geochemical fields for Icelandic source volcanoes are based on data presented in Jakobsson (1979; 2008), Boygle (1994), Hunt et al. (1995), Dugmore and Newton (1998), Haflidason et al. (2000) and references within, Davies et al. (2001), Wastegård et al. (2001,2006), Larsen et al. (2002), Andrews et al. (2002), Mortensen et al. (2005), Óladottir et al. (2008, 2011a and b). Data shown are normalised values. Error bars represent 2 standard deviations of replicate analyses of the BCR2G reference glass.

Figure 8 The Greenland tephra lattice highlighting the most extensive deposits that can be traced in at least two cores. The deposits shown in red can be traced between all 3 cores, those in green correlate between NGRIP and NEEM and those in orange correlate between NGRIP and GRIP. The positions of other tephra deposits found in just one core are also shown. Tephra correlations are based on results outlined in this study, Rasmussen et al (in press) and Seierstad et al., (in review) (see Table 3). The Greenland event stratigraphy and NGRIP $\delta^{18} \mathrm{O}$ curve plotted on the GICC05 timescale (Andersen et al., 2006) GI (interstadial) and GS (stadial) events are shown according to Rasmussen et al. (in review).

Figure 9 Geochemical biplots that support the new tephra correlations between ice-cores shown in Figure 8 and Table 3. A) Period 1 correlations: i) $\mathrm{TiO}_{2}$ vs. $\mathrm{CaO}$ biplot and ii) $\mathrm{MgO}$ vs. $\mathrm{CaO}$ biplot for GRIP $2049.50 \mathrm{~m}$ (this study), NEEM $1656.50 \mathrm{~m}$ (this study) and NGRIP 
1895.24 m of Davies et al., (2010); GRIP 2060.85 m (this study) to NGRIP $1908.70 \mathrm{~m}$ and NEEM 1664.95 (Rasmussen et al., 2013) and GRIP 2079.40 (this study) to NEEM $1677.60 \mathrm{~m}$ and NGRIP 1929.95 m (Rasmussen et al., 2013). B) Period 2 correlation between NEEM 1702.45 $\mathrm{m}$ and NGRIP $1873.16 \mathrm{~m}$ (this study) $\mathrm{Bi}$ ) $\mathrm{Al}_{2} \mathrm{O}_{3}$ vs. $\mathrm{TiO}_{2}$ biplot and $\mathrm{Bii}$ ) $\mathrm{FeO} / \mathrm{MgO}$ vs. $\mathrm{TiO}_{2}$ biplot. C) Period 3 correlations $\mathrm{Ci}$ ) $\mathrm{CaO}$ vs. $\mathrm{TiO}_{2}$ and $\mathrm{Cii}$ ) $\mathrm{FeO} / \mathrm{MgO}$ vs. $\mathrm{TiO}_{2}$. NEEM and NGRIP data presented are from Bourne et al., (2013). Data shown are normalised values. Error bars represent 2 standard deviations of replicate analyses of the BCR2G reference glass.

Figure 10 A) Tephra grain-size data for each deposit relative to distance of core locations from Katla. B) Tephra grain-size data for each deposit relative to distance of core locations from Grimsvötn.

Figure 11 - A Greenland tephrochronology framework for 25-45 ka b2k highlighting those tephras that are geochemically distinct (bold italic type) from other deposits of similar age and those that fall close to rapid climatic events. Tephra layers are highlighted that lie on a sharp transition in the Greenland event stratigraphy of Rasmussen et al. (in review).

Figure 12 - Geochemical comparisons of tephra deposits that fall on climatic transitions relative to other tephra layers of similar age (see stratigraphic positions in Figure 11). A) Tephra deposits in GS-3 and GI-3; B) Tephra deposits in GI-4 and GS-5.1; C) Tephra deposits in GS-5.1 and GI-5.1; D) Tephra deposits in GI-5.2 and GS-6, E) Tephra deposits in GI-6 and GI-7; F) Tephra deposits in GI-8 and GS-9 and G) Tephra deposits in GI-9, GS-10 and GI-10. Data shown are normalised values. Error bars represent 2 standard deviations of 
replicate analyses of the $\mathrm{BCR} 2 \mathrm{G}$ reference glass for basaltic layers and of the Lipari Obsidian for silicic layers.

Figure 13 - NGRIP cryptotephra positions plotted alongside chemostratigraphical data. A) Electrical Conductivity measurement (ECM) for 25-45 ka b2k. B) Dust, Calcium, Sulphate and Conductivity measurements between GI-8 and GI-9 and C) Expanded interstadial (Ci) and stadial section (Cii). Sulphate, calcium, electrolytic meltwater conductivity and dust analyses have been measured by the continuous flow analysis (CFA) system. Tephra positions are shown by the red lines and shading and ice sections sampled for tephra content in A) are shown by grey shading.

Table 1: Summary table of tephra deposits identified in each ice-core within the different time periods. Number of tephra deposits already published and noted in parentheses are from Period 1: Davies et al., (2010) and Period 3: Bourne et al., (2013). Grain size was measured using a graticule in the eye-piece of a transmitted light microscope.

Table 2: Tephra framework for the Greenland ice-cores spanning 25-45 ka b2k. For each tephra the following information is provided: depth interval of ice sampled, shard numbers identified per sample, climatic event within which tephra was deposited (according to Rasmussen et al., in review), age, grain-size data, geochemical composition and most likely volcanic source. Shard numbers are given for each sample but are not directly comparable with one another due to differences in sample volume. Shading highlights 2 or 3 layers from different ice-cores that have been correlated according to Rasmussen et al., (2013) (denoted by ${ }^{\#}$ ) and Seierstad et al., (in review) (denoted by ${ }^{\wedge}$ ), any unmarked shaded layers represent new correlations discussed here and outlined in Table 3 and Figure 8. The climatic event is 
defined based upon the event stratigraphy presented in Rasmussen et al., (in review). Ages are in b2k (before $2000 \mathrm{CE}$ ) and represent the age of the basal depth of the ice sample containing the glass shards. The ages are obtained from the GICC05 timescale in steps of 20 years for the NGRIP core (Andersen et al., 2006, Svensson et al., 2006, 2008) and the GRIP core (Seierstad et al., in review) and in steps of $0.55 \mathrm{~cm}$ for the NEEM core (Rasmussen et al., 2013). DYE-3 ages are approximate ages based on wiggle-matching of $\delta^{18} \mathrm{O}$ to NGRIP. MCE = maximum counting error; in a standard deviation context, the maximum counting error should be regarded as 2 sigma (Andersen et al., 2006; Rasmussen et al., 2006). Ages for deposits which have been traced and correlated between cores (indicated by shading) may differ because 1) they are basal ages for the sample within which glass shards were identified, 2) that the exact position of the tephra horizon within the ice sample is unknown, 3) the depth range of the sample is different from core to core, and 4) due to the uncertainty on the timescale transfer from NGRIP to GRIP and NEEM. Chemical composition after Le Bas et al., (1986): $\mathrm{TB}=$ Tholeiitic Basalt, $\mathrm{TAB}=$ Transitional Alkali Basalt, $\mathrm{B}=$ Basalt, $\mathrm{R}=$ Rhyolite, Da $=$ Dacite, TRDA $=$ Trachydacite $. \dagger=$ Tephra deposits published by Davies et al., (2010) and * = Tephra deposits published by Bourne et al., (2013).

Table 3: Summary of tephra horizons that have been correlated between different ice-core records from Rasmussen et al., (2013), Seierstad et al. (submitted) and this study. Similarity coefficient (SC) and statistical distance (SD) comparisons for tephra horizon correlations are presented. The similarity coefficient method is from Borchardt et al., (1972) and Hunt et al., (1995) and 7 major elements were used in the comparisons. The statistical distance method is from Perkins et al., $(1998 ; 1995)$ and 10 major elements were used in the comparisons. Critical value for testing the statistical distance values at the $99 \%$ confidence interval is 23.21 
821 (10 degrees of freedom). Correlations highlighted in bold were used as time-scale transfer 822 points in the respective studies.

823

824 Supplementary Data: Major element data for each tephra deposit analysed in this study. Data 825 are separated into four worksheets according to periods 1-4 outlined in the main text. The 826 date of analysis and beam size are given. EPMA operating conditions are adapted from 827 Hayward (2012) and vary by beam size and are as follows: $5 \mu \mathrm{m}$ beam diameter 828 Accelerating voltage: $15 \mathrm{kV}$ Beam Current: $2 \mathrm{nA}$ for $\mathrm{Na}, \mathrm{K}, \mathrm{Si}, \mathrm{Al}, \mathrm{Mg}, \mathrm{Fe}, \mathrm{Ca}$ and $80 \mathrm{nA}$ for $829 \mathrm{Mn}, \mathrm{Ti}$, P. $3 \mu \mathrm{m}$ beam diameter - Accelerating voltage: $15 \mathrm{kV}$ Beam Current: $0.5 \mathrm{nA}$ for Na, $830 \mathrm{Al}, 2 \mathrm{nA}$ for $\mathrm{K}, \mathrm{Si}, \mathrm{Mg}, \mathrm{Fe}, \mathrm{Ca}$ and $60 \mathrm{nA}$ for Mn, Ti, P. Analyses of the reference standard glasses BCR2G and Lipari are given in the Standard data sheet. They are ordered by date of analysis and were conducted throughout the analytical period. Recommended values for the Lipari from Kuehn et at. al. (2011) and for BCR2G from http://minerals.cr.usgs.gov/geo_chem_stand/basaltbcr2.html (accessed 12/06/13) are given.

\section{References}

838

Abbott, P.M., Davies, S.M., 2012. Volcanism and the Greenland ice-cores: the tephra record. 840 Earth-Sci Rev 115, 173-191.

841 Abbott, P.M., Davies, S.M., Steffensen, J.P., Pearce, N.J.G., Bigler, M., Johnsen, S.J., 842 Seierstad, I.K., Svensson, A., Wastegard, S., 2012. A detailed framework of Marine Isotope 843 Stages 4 and 5 volcanic events recorded in two Greenland ice-cores. Quaternary Science 844 Reviews 36, 59-77. 
845 Andersen, K.K., Svensson, A., Johnsen, S.J., Rasmussen, S.O., Bigler, M., Rothlisberger, R., 846 Ruth, U., Siggaard-Andersen, M.L., Steffensen, J.P., Dahl-Jensen, D., Vinther, B.M., 847 Clausen, H.B., 2006. The Greenland Ice Core Chronology 2005, 15-42 ka. Part 1: 848 constructing the time scale. Quaternary Science Reviews 25, 3246-3257.

849 Andrews, J.T., Geirsdottir, A., Hardardottir, J., Principato, S., Gronvold, K., Kristjansdottir, 850 G.B., Helgadottir, G., Drexler, J., Sveinbjornsdottir, A., 2002. Distribution, sediment 851 magnetism and geochemistry of the Saksunarvatn $(10,180+/-60$ cal. yr BP) tephra in marine, 852 lake, and terrestrial sediments, northwest Iceland. Journal of Quaternary Science 17, 731-745.

Arnalds, O., Thorarinsdottir, E.F., Thorsson, J., Waldhauserova, P.D., Agustsdottir, A.M., 2013. An extreme wind erosion event of the fresh Eyjafjallajokull 2010 volcanic ash. Sci 855 Rep-Uk 3.

Bigler, M., 2004. Hochauflosende Spurenstoffmessungen an polaren Eisbohrkernen: Glazio857 chemische und klimatische Prozessstudien. University of Bern, Switzerland.

Blockley, S.P.E., Lane, C.S., Hardiman, M., Rasmussen, S.O., Seierstad, I.K., Steffensen, 859 J.P., Svensson, A., Lotter, A.F., Turney, C.S.M., Ramsey, C.B., Intimate, 2012. 860 Synchronisation of palaeoenvironmental records over the last 60,000 years, and an extended INTIMATE(1) event stratigraphy to 48,000 b2k. Quaternary Science Reviews 36, 2-10. A.M., Turney, C.S.M., Molyneux, E.G., 2005. A new and less destructive laboratory procedure for the physical separation of distal glass tephra shards from sediments. Quaternary Science Reviews 24, 1952-1960. 
Borchardt, G.A., Aruscavage, P.J. and Millard, H. Jr., 1972. Correlation of the Bishop ash, a Pleistocene marker bed, using instrumental neutron activation analysis. Journal of Sedimentary Petrology 42, 201-206.

Bourne, A.J., Davies, S.M., Abbott, P.M., Rasmussen, S.O., Steffensen, J.P., Svensson, A.,, 2013. Revisiting the Faroe Marine Ash Zone III in two Greenland ice cores: implications for marine-ice correlations. Journal of Quaternary Science 28, 641-646.

Boygle, J.E., 1994. Tephra in lake sediments: an unambiguous geochronological marker? University of Edinburgh, Edinburgh.

Coulter, S.E., Pilcher, J.R., Plunkett, G., Baillie, M., Hall, V.A., Steffensen, J.P., Vinther, B.M., Clausen, H.B., Johnsen, S.J., 2012. Holocene tephras highlight complexity of volcanic signals in Greenland ice cores. J Geophys Res-Atmos 117.

Dahl-Jensen, D., Gundestrup, N., Miller, H., Watanabe, O., Johnsen, S.J., Steffensen, J.P., Clausen, H.B., 1170 Svensson, A., Larsen, L.B., 2002. The NorthGRIP deep drilling program. Annals of Glaciology 35, 1-4.

Dansgaard, W., Johnsen, S.J., Clausen, H.B., Dahljensen, D., Gundestrup, N.S., Hammer, C.U., Hvidberg, C.S., Steffensen, J.P., Sveinbjornsdottir, A.E., Jouzel, J., Bond, G., 1993. Evidence for General Instability of Past Climate from a 250-Kyr Ice-Core Record. Nature $364,218-220$.

Davies SM, A.P., Meara RH., Pearce NJG., Austin, WEN., Chapman, MR., Svensson A., Bigler M., Rasmussen T., in press. A North Atlantic tephra framework for 130,000 - 60,000 years b2k: new tephra discoveries, marine based-correlations and future challenges. Quaternary Science Reviews. 
890

891

892

893

894

895

896

897

898

899

900

901

902

903

904

905

906

907

908

909

910

911

912

Davies, S.M., Abbott, P.M., Pearce, N.J.G., Wastegard, S., Blockley, S.P.E., 2012. Integrating the INTIMATE records using tephrochronology: rising to the challenge. Quaternary Science Reviews 36, 11-27.

Davies, S.M., Wastegard, S., Abbott, P.M., Barbante, C., Bigler, M., Johnsen, S.J., Rasmussen, T.L., Steffensen, J.P., Svensson, A., 2010. Tracing volcanic events in the NGRIP ice-core and synchronising North Atlantic marine records during the last glacial period. Earth and Planetary Science Letters 294, 69-79.

Davies, S.M., Wastegard, S., Rasmussen, T.L., Svensson, A., Johnsen, S.J., Steffensen, J.P., Andersen, K.K., 2008. Identification of the Fugloyarbanki tephra in the NGRIP ice core: a key tie-point for marine and ice-core sequences during the last glacial period. Journal of Quaternary Science 23, 409-414.

Davies, S.M., Turney, C.S.M., Lowe, J.J., 2001. Identification and significance of a visible, basalt-rich Vedde Ash layer in a Late-glacial sequence on the Isle of Skye, Inner Hebrides, Scotland. Journal of Quaternary Science 16, 99-104.

De Vivo, B., Rolandi, G., Gans, P.B., Calvert, A., Bohrson, W.A., Spera, F.J., Belkin, H.E., 2001. New constraints on the pyroclastic eruptive history of the Campanian volcanic Plain (Italy). Mineralogy and Petrology 73, 47-65.

Demuro, M., Roberts, R.G., Froese, D.G., Arnold, L.J., Brock, F., Ramsey, C.B., 2008. Optically stimulated luminescence dating of single and multiple grains of quartz from perennially frozen loess in western Yukon Territory, Canada: Comparison with radiocarbon chronologies for the late Pleistocene Dawson tephra. Quaternary Geochronology 3, 346-364.

Dugmore, A.J., Newton, A.J., 1998. Holocene tephra layers in the Faroe Islands. Frodskaparrit 46, 191-204. 
913 Griggs, A.J., Davies, S.M., Abbott, P.M., Rasmussen, T.L., Palmer, A.P, in press. Optimising 914 the use of marine tephrochronology in the North Atlantic: a detailed investigation of the 915 Faroe Marine Ash Zones II, III and IV. Quaternary Science Reviews.

916 Grönvold, K., Jóhannesson, H., 1984. Eruption in Grímsvötn 1983; Course of events and 917 chemical studies of the tephra. Jökull 34, 1-10.

918 Grönvold, K., Oskarsson, N., Johnsen, S.J., Clausen, H.B., Hammer, C.U., Bond, G., Bard, 919 E., 1995. Ash layers from Iceland in the GRIP ice core correlated with oceanic and land 920 sediments. Earth and Planetary Science Letters 135, 149-155.

Haflidason, H., Eiriksson, J., Van Kreveld, S., 2000. The tephrochronology of Iceland and the North Atlantic region during the Middle and Late Quaternary: a review. Journal of Quaternary Science 15, 3-22. Hayward, C., 2012. High spatial resolution electron probe microanalysis of tephras and melt inclusions without beam-induced chemical modification. Holocene 22, 119-125.

926 Hunt, J.B., Fannin, N.G.T., Hill, P.G., Peacock, J.D., 1995. The tephrochronology and 927 radiocarbon dating of North Atlantic, late Quaternary sediments: an example from the St 928 Kilda Basin, In: Scrutton, R.A., Stoker, M. S., Shimmield, G. B., Tudhope, A. W. (Ed.), The 929 Tectonics, Sedimentation and Palaeoceanography of the North Atlantic Region, London, pp. 930 227-248.

Jakobsson, S.P., 1979. Outline of the petrology of Iceland. Jökull 29, 57-73. 117-138. 
Kuehn S.C., Froese D.G., Shane P.A.R., 2011. The INTAV intercomparison of electron-beam microanalysis of glass by tephrochronology laboratories: Results and recommendations. Quaternary International 246, 19-48.

Larsen, G., Eiríksson, J., 2007. Late Quaternary terrestrial tephrochronology of Icelandfrequency of explosive eruptions, type and volume of tephra deposits. Journal of Quaternary Science 23, 109-120.

Larsen, G., Eiriksson, J., Knudsen, K.L., Heinemeier, J., 2002. Correlation of late Holocene terrestrial and marine tephra markers, north Iceland: implications for reservoir age changes. Polar Res 21, 283-290.

Le Bas, M.J., Le Maitre, R.W., Streckeisen, A., Zanettin, B., 1986. A chemical classification of volcanic rocks based on the Total Alkali-Silica diagram. Journal of Petrology 27, 745-750.

Mackie, E.A.V., Davies, S.M., Turney, C.S.M., Dobbyn, K., Lowe, J.J., Hill, P.G., 2002. The use of magnetic separation techniques to detect basaltic microtephra in last glacialinterglacial transition (LGIT; 15-10 ka cal. BP) sediment sequences in Scotland. Scot J Geol $38,21-30$.

Meara, R.H., 2011. Geochemical fingerprinting of Icelandic silicic Holocene tephra layers. University of Edinburgh, Edinburgh, p. 338.

Mortensen, A.K., Bigler, M., Gronvold, K., Steffensen, J.P., Johnsen, S.J., 2005. Volcanic ash layers from the Last Glacial Termination in the NGRIP ice core. Journal of Quaternary Science 20, 209-219.

NGRIP Members, 2004. High-resolution record of Northern Hemisphere climate extending into the last interglacial period. . Nature, 147-151. 
958 Óladóttir, B.A., Sigmarsson, O., Larsen, G., Thordarson, T., 2008. Katla volcano, Iceland: 959 magma composition, dynamics and eruption frequency as recorded by Holocene tephra 960 layers. Bulletin of Volcanology 70, 475-493.

961 Óladóttir, B., Larsen, G., Sigmarsson, O., 2011a. Holocene volcanic activity at Grímsvötn, 962 Bárdarbunga and Kverkfjöll subglacial centres beneath Vatnajökull, Iceland. Bulletin of 963 Volcanology 73, 1187-1208.

964

965 Óladóttir, B.A., Sigmarsson, O., Larsen, G., Devidal, J.-L., 2011b. Provenance of basaltic 966 tephra from Vatnajökull subglacial volcanoes, Iceland, as determined by major- and trace967 element analyses. The Holocene 21, 1037-1048.

968

969 Perkins, M.E., Brown, F. H., Nash, W. P., Williams, S. K., and McIntosh, W., 1998. 970 Sequence, age, and source of silicic fallout tuffs in middle to late Miocene basins of the 971 northern Basin and Range province. Bulletin of the Geological Society of America 110, 344972360.

974 Perkins, M.E., Nash, W. P., Brown, F. H., and Fleck, R. J., 1995. Fallout tuffs of Trapper 975 Creek, Idaho - A record of Miocene explosive volcanism in the Snake River Plain volcanic 976 province. Bulletin of the Geological Society of America 107, 1484-1506.

977

978 Prospero, J.M., Bullard, J.E., Hodgkins, R., 2012. High-Latitude Dust Over the North 979 Atlantic: Inputs from Icelandic Proglacial Dust Storms. Science 335, 1078-1082. 
980

981

982

983

984

985

986

987

988

989

990

991

992

993

994

995

996

997

998

999

1000

1001

1002

Pyle, D.M., Ricketts, G.D., Margari, V., van Andela, T.H., Sinitsyn, A.A., Praslov, N.D., Lisitsyn, S., 2006. Wide dispersal and deposition of distal tephra during the Pleistocene 'Campanian Ignimbrite/Y5' eruption, Italy. Quaternary Science Reviews 25, 2713-2728.

Ram, M., Gayley R.I., 1991. Long-range transport of volcanic ash to the Greenland Ice Sheet, Nature, 349, 401-404.

Ram, M., Donarummo, J. Jr., Sheridan, M.,, . 1996. Volcanic ash from Icelandic 57, 300 yr BP eruption found in GISP 2 (Greenland) ice core. Geophysical Research Letters 23, 31673169.

Rasmussen, S.O., Abbott, P.M., Blunier, T., Bourne, A.J., Brook, E., Buchardt, S.L., Buizert, C., Chappellaz, J., Clausen, H.B., Cook, E., Dahl-Jensen, D., Davies, S.M., Guillevic, M., Kipfstuhl, S., Laepple, T., Seierstad, I.K., Severinghaus, J.P., Steffensen, J.P., Stowasser, C., Svensson, A., Vallelonga, P., Vinther, B.M., Wilhelms, F., Winstrup, M., 2013. A first chronology for the North Greenland Eemian Ice Drilling (NEEM) ice core. Climate of the Past 9, 2713-2730.

Rasmussen, S.O., Andersen, K.K., Svensson, A.M., Steffensen, J.P., Vinther, B.M., Clausen, H.B., Siggaard-Andersen, M.L., Johnsen, S.J., Larsen, L.B., Dahl-Jensen, D., Bigler, M., Rothlisberger, R., Fischer, H., Goto-Azuma, K., Hansson, M.E., Ruth, U., 2006. A new Greenland ice core chronology for the last glacial termination. J Geophys Res-Atmos 111.

Rasmussen, S.O., Bigler, M., Blockley, S.P.E., Blunier, T., Buchardt, S.L., Clausen, H.B., Cvijanovic, I., Dahl-Jensen, D., Johnsen, S.J., Fischer, H., Gkinis, V., Guillevic, M., Hoek, W.Z., Lowe, J.J., Pedro, J., Popp, T., Seierstad, I., Steffensen, J.P., Svensson, A.M., Vallelonga, P., Vinther, B.M., Walker, M.J.C., Wheatley, J.J., Winstrup, M., in review. A framework for robust naming and correlation of past abrupt climatic changes during the 
recent glacial period based on three synchronised Greenland ice-cores. . Quaternary Science 1004 Reviews.

1005

1006

1007

1008

1009

1010

1011

1012

1013

1014

1015

1016

1017

1018

1019

1020

1021

1022

1023

1024

1025

1026

Seierstad, I.K., Abbott, P.M., Bigler, M., Blunier, T., Bourne, A.J., Brook, E., Buchardt, S.L., Buizert, C., Clausen, H.B., Cook, E., Dahl-Jensen, D., Davies, S.M., Guillevic, M., Johnsen, S.J., Pedersen, D.S., Popp, T.J., Rasmussen, S.O., Severinghaus, J., Svensson, A., Vinther, B.M., in review. Consistently dated records from the Greenland GRIP, GISP2 and NGRIP ice cores for the past $104 \mathrm{ka}$ reveal regional millennial-scale isotope gradients with possible Heinrich Event imprint. Quaternary Science Reviews

Steffensen, J.-P., 1995. Microparticles and chemical impurities in ice cores from Dye-3, South Greenland, and their interpretation in palaeoclimatic reconstructions, Niels Bohr Institute. University of Copenhagen, Copenhagen.

Svensson, A., Andersen, K.K., Bigler, M., Clausen, H.B., Dahl-Jensen, D., Davies, S.M., Johnsen, S.J., Muscheler, R., Parrenin, F., Rasmussen, S.O., Roethlisberger, R., Seierstad, I., Steffensen, J.P., Vinther, B.M., 2008. A 60000 year Greenland stratigraphic ice core chronology. Climate of the Past 4, 47-57.

Svensson, A., Andersen, K.K., Bigler, M., Clausen, H.B., Dahl-Jensen, D., Davies, S.M., Johnsen, S.J., Muscheler, R., Rasmussen, S.O., Rothlisberger, R., Steffensen, J.P., Vinther, B.M., 2006. The Greenland Ice Core Chronology 2005, 15-42 ka. Part 2: comparison to other records. Quaternary Science Reviews 25, 3258-3267.

Svensson, A., Bigler, M., Blunier, T., Clausen, H.B., Dahl-Jensen, D., Fischer, H., Fujita, S., Goto-Azuma, K., Johnsen, S.J., Kawamura, K., Kipfstuhl, S., Kohno, M., Parrenin, F., Popp, T., Rasmussen, S.O., Schwander, J., Seierstad, I., Severi, M., Steffensen, J.P., Udisti, R., Uemura, R., Vallelonga, P., Vinther, B.M., Wegner, A., Wilhelms, F., Winstrup, M., 2013. 
Direct linking of Greenland and Antarctic ice cores at the Toba eruption (74 ka BP). Climate of the Past 9, 749-766.

Turney, C.S.M., 1998. Extraction of rhyolitic ash from minerogenic lake sediments. Journal of Paleolimnology 1146, 199-206.

Vinther, B.M., Clausen, H.B., Johnsen, S.J., Rasmussen, S.O., Andersen, K.K., Buchardt, S.L., Dahl-Jensen, D., Seierstad, I.K., Siggaard-Andersen, M.L., Steffensen, J.P., Svensson, A., Olsen, J., Heinemeier, J., 2006. A synchronized dating of three Greenland ice cores throughout the Holocene. J Geophys Res-Atmos 111.

Wastegård, S., Bjorck, S., Grauert, M., Hannon, G.E., 2001. The Mjauvotn tephra and other Holocene tephra horizons from the Faroe Islands: a link between the Icelandic source region, the Nordic Seas, and the European continent. Holocene 11, 101-109.

Wastegård, S., Rasmussen T.L., Kuijpers A., Nielsen, T., van Weering, T.C.E., 2006. Composition and origin of ash zones from Marine Isotope Stages 3 and 2 in the North Atlantic. Quaternary Science Reviews 25, 2409-2419.

Zielinski, G.A., Mayewski, P.A., Meeker, L.D., Gronvold, K., Germani, M.S., Whitlow, S., Twickler, M.S., Taylor, K., 1997. Volcanic aerosol records and tephrochronology of the Summit, Greenland, ice cores. Journal of Geophysical Research-Oceans 102, 26625-26640.

Zielinski, G.A., Mayewski, P.A., Meeker, L.D., Whitlow, S., Twickler, M.S., 1996. A 110,000 year record of explosive volcanism from the GISP2 (Greenland) ice core. Quaternary Research 45, 109-118. 


\begin{tabular}{|c|c|c|c|c|c|}
\hline & Ice Core & $\begin{array}{c}\text { Total number } \\
\text { of tephra } \\
\text { deposits } \\
\text { (published) }\end{array}$ & $\begin{array}{c}\text { Ice } \\
\text { Sampled } \\
(\mathrm{m})\end{array}$ & $\begin{array}{l}\% \text { of Total } \\
\text { Ice in } \\
\text { Period }\end{array}$ & $\begin{array}{c}\text { Tephra } \\
\text { average grain } \\
\text { size }(\mu \mathrm{m})\end{array}$ \\
\hline \multirow{4}{*}{ 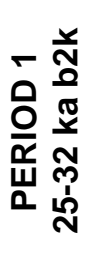 } & NEEM & 9 & 30.80 & 44 & 27.1 \\
\hline & NGRIP & $8(6)$ & 55.55 & 46 & 33.5 \\
\hline & GRIP & 12 & 52.80 & 48 & 36.8 \\
\hline & DYE-3 & 8 & 15.40 & 40 & 57.3 \\
\hline \multirow{4}{*}{ 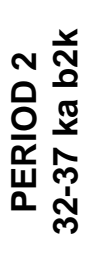 } & NEEM & 4 & 26.40 & 37 & 18.6 \\
\hline & NGRIP & 5 & 50.05 & 40 & 30.6 \\
\hline & GRIP & 0 & 0 & 0 & $\mathrm{~N} / \mathrm{A}$ \\
\hline & DYE-3 & 0 & 0.00 & 0 & $N / A$ \\
\hline \multirow{4}{*}{ 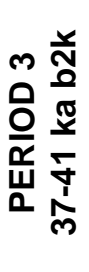 } & NEEM & $2(5)$ & 26.40 & 86 & 25.0 \\
\hline & NGRIP & $0(15)$ & 45.65 & 91 & 29.3 \\
\hline & GRIP & 10 & 45.10 & 100 & 45.6 \\
\hline & DYE-3 & 7 & 18.70 & 100 & 54.6 \\
\hline \multirow{4}{*}{ 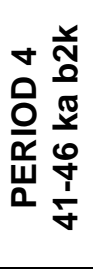 } & NEEM & 0 & 8.80 & 18 & $\mathrm{~N} / \mathrm{A}$ \\
\hline & NGRIP & 8 & 30.25 & 34 & 28.1 \\
\hline & GRIP & 0 & 0.00 & 0 & $\mathrm{~N} / \mathrm{A}$ \\
\hline & DYE-3 & 0 & 0.00 & 0 & $\mathrm{~N} / \mathrm{A}$ \\
\hline
\end{tabular}




\begin{tabular}{|c|c|c|c|c|c|c|c|}
\hline & Tephra layer & $\begin{array}{l}\text { Depth Range } \\
\text { (m) }\end{array}$ & $\begin{array}{l}\text { Shards per } \\
\text { Sample }\end{array}$ & $\begin{array}{c}\text { Climatic } \\
\text { Event }\end{array}$ & $\begin{array}{l}\text { Age of base } \pm \\
\text { MCE (yr b2k) }\end{array}$ & $\begin{array}{c}\text { Average } \\
\text { Grain Size } \\
(\mu \mathrm{m})\end{array}$ & $\begin{array}{l}\text { Max Grain } \\
\text { Size }(\mu \mathrm{m})\end{array}$ \\
\hline \multirow{23}{*}{$\begin{array}{l}\overline{\mathbf{0}} \\
\frac{\mathbf{0}}{\boldsymbol{\alpha}} \\
\underline{\mathbf{n}}\end{array}$} & NEEM $1626.15 \mathrm{~m}$ & $1626.1-1626.15$ & 1055 & GS-3 & $26439 \pm 766$ & 22.0 & 80.0 \\
\hline & GRIP $2002.20 \mathrm{~m}$ & 2002.00-2002.20 & 361 & GS-3 & $26544 \pm 768$ & 50.9 & 67.5 \\
\hline & NGRIP $1848.05 \mathrm{~m}^{\dagger}$ & $1848.00-1848.05$ & Visible & GS-3 & $26743 \pm 780$ & 38.8 & 62.5 \\
\hline & NGRIP $1855.80 \mathrm{~m}^{\dagger}$ & $1855.70-1855.80$ & 24 & GS-3 & $27198 \pm 804$ & 45.5 & 62.5 \\
\hline & NEEM $1636.45 \mathrm{~m}$ & $1636.25-1636.45$ & 19 & GS-3 & $27510 \pm 820$ & 28.0 & 60.0 \\
\hline & NEEM $1636.65 \mathrm{~m}$ & $1636.45-1636.65$ & 56 & GS-3 & $27528 \pm 821$ & 30.0 & 60.0 \\
\hline & NGRIP $1861.55 \mathrm{~m}^{\dagger}$ & $1861.45-1861.55$ & 103 & GS-3 & $27534 \pm 821$ & 37.3 & 52.5 \\
\hline & NGRIP $1882.10 \mathrm{~m}^{\#}$ & $1881.95-1882.10$ & 51 & GS-4 & $28575 \pm 886$ & 23.3 & 32.5 \\
\hline & NEEM $1648.90 \mathrm{~m}^{\#}$ & $1648.75-1648.90$ & 214 & GS-4 & $28578 \pm 885$ & 36.0 & 70.0 \\
\hline & NGRIP 1882.50 m & 1882.30-1882.50 & 48 & GS-4 & $28594 \pm 887$ & 33.5 & 50.0 \\
\hline & NGRIP $1888.10 \mathrm{~m}$ & $1888.05-1888.10$ & 70 & GI-4 & $28789 \pm 893$ & 29.5 & 47.5 \\
\hline & NGRIP 1894.05 m & $1893.85-1894.05$ & 25 & GS-5.1 & $29048 \pm 905$ & 46.6 & 80.0 \\
\hline & NGRIP $1895.24 \mathrm{~m}^{\dagger \#}$ & 1895.23-1895.24 & Visible & GS-5.1 & $29132 \pm 912$ & 44.0 & 75.0 \\
\hline & NEEM $1656.50 \mathrm{~m}^{\#}$ & $1656.45-1656.50$ & 2004 & GS-5.1 & $29135 \pm 911$ & 40.0 & 105.0 \\
\hline & GRIP $2049.50 \mathrm{~m}$ & 2049.30-2049.50 & 1747 & GS-5.1 & $29147 \pm 912$ & 50.8 & 80.0 \\
\hline & GRIP $2060.85 \mathrm{~m}$ & $2060.70-2060.85$ & 429 & GS-5.1 & $30066 \pm 976$ & 33.3 & 45.0 \\
\hline & NGRIP $1908.70 \mathrm{~m}^{\#}$ & $1908.50-1908.70$ & 250 & GS-5.1 & $30082 \pm 977$ & 26.3 & 47.5 \\
\hline & NEEM $1664.95 \mathrm{~m}^{\#}$ & $1664.85-1664.95$ & 80 & GS-5.1 & $30083 \pm 977$ & 16.3 & 30.0 \\
\hline & GRIP $2061.40 \mathrm{~m}$ & 2061.25-2061.40 & 11 & GS-5.1 & $30111 \pm 978$ & 33.3 & 45.0 \\
\hline & GRIP 2064.35 m & 2064.15-2064.35 & & GS-5.1 & $30353 \pm 993$ & 23.0 & 35.0 \\
\hline & NGRIP 1913.10 m & $1912.90-1913.10$ & 1028 & GS-5.1 & $30394 \pm 995$ & 11.3 & 20.0 \\
\hline & GRIP $2066.75 \mathrm{~m}$ & 2066.55-2066.75 & 288 & GS-5.1 & $30551 \pm 1005$ & 36.2 & 65.0 \\
\hline & NGRIP $1915.50 \mathrm{~m}^{\dagger \#}$ & $1915.10-1915.50$ & 92 & GS-5.1 & $30565 \pm 1006$ & 42.0 & 60.0 \\
\hline
\end{tabular}




\begin{tabular}{|c|c|c|c|c|c|c|c|}
\hline & Tephra layer & $\begin{array}{l}\text { Depth Range } \\
\text { (m) }\end{array}$ & $\begin{array}{c}\text { Shards per } \\
\text { Sample }\end{array}$ & $\begin{array}{c}\text { Climatic } \\
\text { Event }\end{array}$ & $\begin{array}{l}\text { Age of base } \pm \\
\text { MCE (yr b2k) }\end{array}$ & $\begin{array}{c}\text { Average } \\
\text { Grain Size } \\
(\mu \mathrm{m})\end{array}$ & $\begin{array}{l}\text { Max Grain } \\
\text { Size }(\mu \mathrm{m})\end{array}$ \\
\hline \multirow{20}{*}{ 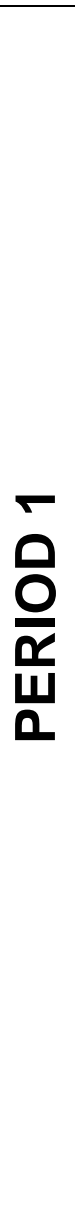 } & NGRIP $1915.63 \mathrm{~m}^{\dagger \#}$ & $1915.50-1915.63$ & 84 & GS-5.1 & $30573 \pm 1007$ & 47.0 & 77.5 \\
\hline & NEEM $1669.25 \mathrm{~m}^{\#}$ & $1669.10-1669.25$ & 188 & GS-5.1 & $30590 \pm 1007$ & 25.1 & 40.0 \\
\hline & GRIP 2067.85 m & $2067.65-2067.85$ & 55 & Gl-5.1 & $30628 \pm 1010$ & 32.2 & 47.5 \\
\hline & GRIP $2070.20 \mathrm{~m}$ & $2070.05-2070.20$ & 74 & GI-5.1 & $30779 \pm 1022$ & 28.5 & 50.0 \\
\hline & GRIP $2070.75 \mathrm{~m}$ & $2070.60-2070.75$ & 6 & GI-5.1 & $30813 \pm 1023$ & 53.2 & 80.0 \\
\hline & NEEM $1671.85 \mathrm{~m}$ & $1671.65-1671.85$ & 135 & GI-5.1 & $30825 \pm 1023$ & 25.7 & 55.0 \\
\hline & GRIP $2079.40 \mathrm{~m}^{\wedge}$ & $2079.00-2079.40$ & 1499 & GS-5.2 & $31414 \pm 1066$ & 51.3 & 87.5 \\
\hline & NGRIP $1929.95 \mathrm{~m}^{\wedge}$ & 1929.80-1929.95 & 130 & GS-5.2 & $31432 \pm 1067$ & 32.1 & 45.0 \\
\hline & NEEM $1677.60 \mathrm{~m}^{\#}$ & $1677.50-1677.60$ & 69 & GS-5.2 & $31433 \pm 1067$ & 21.3 & 35.0 \\
\hline & NGRIP $1931.60 \mathrm{~m}^{\wedge}$ & $1931.45-1931.60$ & 45 & GS-5.2 & $31543 \pm 1074$ & 22.5 & 30.0 \\
\hline & GRIP $2081.05 \mathrm{~m}^{\wedge}$ & 2080.85-2081.05 & 11 & GS-5.2 & $31555 \pm 1076$ & 30.0 & 45.0 \\
\hline & GRIP $2081.40 \mathrm{~m}$ & $2081.20-2081.40$ & 183 & GS-5.2 & $31581 \pm 1078$ & 34.3 & 57.5 \\
\hline & DYE-3 $1865.70 \mathrm{~m}$ & $1865.60-1865.70$ & 114 & $\mathrm{Gl}-4$ & $28700 \pm 1000$ & 59.0 & 80.0 \\
\hline & DYE-3 $1865.80 \mathrm{~m}$ & $1865.70-1865.80$ & 38 & $\mathrm{Gl}-4$ & $28720 \pm 1000$ & 66.9 & 115.0 \\
\hline & DYE-3 $1865.90 \mathrm{~m}$ & $1865.80-1865.90$ & 17 & GI-4 & $28740 \pm 1000$ & 64.6 & 77.50 \\
\hline & DYE-3 $1866.00 \mathrm{~m}$ & $1865.90-1866.00$ & 12 & Gl-4 & $28760 \pm 1000$ & 56.0 & 92.5 \\
\hline & DYE-3 $1866.10 \mathrm{~m}$ & $1866.00-1866.10$ & 12 & Gl-4 & $28780 \pm 1000$ & 47.5 & 65.0 \\
\hline & DYE-3 $1866.40 \mathrm{~m}$ & $1866.30-1866.40$ & 8 & GI-4 & $28800 \pm 1000$ & 29.2 & 52.5 \\
\hline & DYE-3 $1866.60 \mathrm{~m}$ & $1866.50-1866.60$ & 10 & Gl-4 & $28820 \pm 1000$ & 73.3 & 90.0 \\
\hline & DYE-3 $1869.15 \mathrm{~m}$ & $1869.05-1869.15$ & 9 & GI-5.1 & $29400 \pm 1000$ & 54.2 & 137.5 \\
\hline \multirow{3}{*}{$\begin{array}{l}\mathbf{N} \\
\underline{0} \\
\frac{0}{\tilde{\alpha}} \\
\frac{w}{0}\end{array}$} & NEEM $1689.25 \mathrm{~m}^{\#}$ & $1689.05-1689.25$ & 409 & GI-5.2 & $32459 \pm 1130$ & 18.7 & 37.5 \\
\hline & NGRIP $1950.50 \mathrm{~m}^{\#}$ & $1950.30-1950.50$ & 119 & Gl-5.2 & $32463 \pm 1130$ & 28.8 & 47.5 \\
\hline & NGRIP $1952.15 \mathrm{~m}^{\#}$ & $1951.95-1952.15$ & 29 & GS-6 & $32522 \pm 1132$ & 23.5 & 40.0 \\
\hline
\end{tabular}




\begin{tabular}{|c|c|c|c|c|c|c|c|}
\hline & Tephra layer & $\begin{array}{l}\text { Depth Range } \\
\text { (m) }\end{array}$ & $\begin{array}{c}\text { Shards per } \\
\text { Sample }\end{array}$ & $\begin{array}{c}\text { Climatic } \\
\text { Event }\end{array}$ & $\begin{array}{l}\text { Age of base } \pm \\
\text { MCE (yr b2k) }\end{array}$ & $\begin{array}{c}\text { Average } \\
\text { Grain Size } \\
(\mu \mathrm{m})\end{array}$ & $\begin{array}{l}\text { Max Grain } \\
\text { Size }(\mu \mathrm{m})\end{array}$ \\
\hline \multirow{6}{*}{ 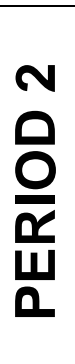 } & NEEM $1690.35 \mathrm{~m}^{\#}$ & $1690.15-1690.35$ & 93 & GS-6 & $32534 \pm 1133$ & 14.1 & 25.0 \\
\hline & NGRIP 1954.70 m & 1954.55-1954.70 & 125 & GS-6 & $32690 \pm 1144$ & 37.1 & 55.0 \\
\hline & NEEM $1693.45 \mathrm{~m}$ & $1693.30-1693.45$ & 15 & GS-6 & $32890 \pm 1165$ & 15.8 & 40.0 \\
\hline & NGRIP $1973.16 \mathrm{~m}$ & 1973.12-1973.16 & 583 & GI-6 & $33686 \pm 1207$ & 38.7 & 75.0 \\
\hline & NEEM $1702.40 \mathrm{~m}$ & $1702.35-1702.40$ & 57 & GI-6 & $33692 \pm 1208$ & 19.0 & 37.5 \\
\hline & NGRIP $2009.15 \mathrm{~m}$ & $2009.00-2009.15$ & 189 & GS-8 & $35470 \pm 1320$ & 24.8 & 37.5 \\
\hline \multirow{17}{*}{ 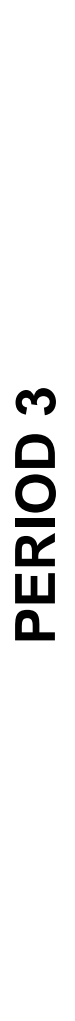 } & NEEM $1747.10 \mathrm{~m}$ & $1746.90-1747.10$ & 317 & GI-8c & $37548 \pm 1429$ & 29.1 & 57.5 \\
\hline & GRIP 2190.65 m & $2190.50-2190.65$ & 6 & GI-8c & $37864 \pm 1435$ & 32.0 & 45.0 \\
\hline & NEEM $1755.60 \mathrm{~m}^{* \#}$ & $1755.45-1755.60$ & 6 & GI-8c & $38040 \pm 1441$ & 20.0 & 25.0 \\
\hline & NGRIP $2064.35 \mathrm{~m}^{\star \# \wedge}$ & $2064.15-2064.35$ & 116 & GI-8c & $38041 \pm 1441$ & 28.9 & 50.0 \\
\hline & GRIP $2195.45 \mathrm{~m}^{\wedge}$ & 2195.25-2195.45 & 9 & Gl-8c & $38043 \pm 1441$ & 51.0 & 72.5 \\
\hline & NGRIP $2065.65 \mathrm{~m}^{*}$ & $2065.45-2065.65$ & 74 & Gl-8c & $38081 \pm 1441$ & 21.1 & 42.5 \\
\hline & NGRIP $2065.80 \mathrm{~m}^{*}$ & $2065.65-2065.80$ & 785 & Gl-8c & $38086 \pm 1442$ & 21.9 & 47.5 \\
\hline & GRIP $2197.45 \mathrm{~m}$ & $2197.25-2197.45$ & 258 & GI-8c & $38115 \pm 1445$ & 47.8 & 65.0 \\
\hline & NEEM $1757.10 \mathrm{~m}^{\star \#}$ & $1756.90-1757.10$ & 19 & GI-8c & $38119 \pm 1445$ & 28.8 & 50.0 \\
\hline & NGRIP $2066.95 \mathrm{~m}^{\star \star \#}$ & 2066.93-2066.95 & Visible & GI-8c & $38121 \pm 1445$ & & \\
\hline & GRIP $2200.75 \mathrm{~m}$ & $2200.55-2200.75$ & 177 & GS-9 & $38249 \pm 1450$ & 49.8 & 97.5 \\
\hline & GRIP $2201.50 \mathrm{~m}^{\wedge}$ & $2201.10-2201.50$ & 200 & GS-9 & $38307 \pm 1452$ & 45.5 & 90.0 \\
\hline & NGRIP $2071.50 \mathrm{~m}^{\star \wedge \#}$ & $2071.30-2071.50$ & 1138 & GS-9 & $38309 \pm 1452$ & 44.8 & 72.5 \\
\hline & NEEM $1759.85 \mathrm{~m}^{\star \#}$ & $1759.65-1759.85$ & 550 & GS-9 & $38311 \pm 1452$ & 25.8 & 50.0 \\
\hline & GRIP 2202.40 m & 2202.20-2202.40 & 6 & GS-9 & $38371 \pm 1456$ & 46.0 & 90.0 \\
\hline & NGRIP $2073.15 \mathrm{~m}^{*}$ & $2072.95-2073.15$ & 10 & GS-9 & $38411 \pm 1461$ & 17.3 & 30.0 \\
\hline & NGRIP $2078.01 \mathrm{~m}^{* \wedge \#}$ & $2077.90-2078.01$ & 32 & GS-9 & $38735 \pm 1476$ & 26.2 & 37.5 \\
\hline
\end{tabular}




\begin{tabular}{|c|c|c|c|c|c|c|c|}
\hline & Tephra layer & $\begin{array}{l}\text { Depth Range } \\
\text { (m) }\end{array}$ & $\begin{array}{c}\text { Shards per } \\
\text { Sample }\end{array}$ & $\begin{array}{c}\text { Climatic } \\
\text { Event }\end{array}$ & $\begin{array}{l}\text { Age of base } \pm \\
\text { MCE (yr b2k) }\end{array}$ & $\begin{array}{c}\text { Average } \\
\text { Grain Size } \\
(\mu \mathrm{m})\end{array}$ & $\begin{array}{l}\text { Max Grain } \\
\text { Size }(\mu \mathrm{m})\end{array}$ \\
\hline \multirow{22}{*}{ 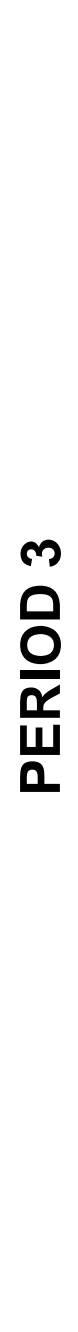 } & GRIP $2207.00 \mathrm{~m}^{\wedge}$ & $2206.60-2207.00$ & 194 & GS-9 & $38748 \pm 1477$ & 43.3 & 62.5 \\
\hline & NEEM $1764.25 \mathrm{~m}^{\star \#}$ & $1764.05-1764.25$ & 12 & GS-9 & $38763 \pm 1477$ & 30.8 & 80.0 \\
\hline & NGRIP 2078.37 m* & 2078.30-2078.37 & 561 & GS-9 & $38759 \pm 1478$ & 22.3 & 42.5 \\
\hline & NGRIP $2078.97 \mathrm{~m}^{*}$ & 2078.85-2078.97 & 126 & GS-9 & $38796 \pm 1479$ & 29.5 & 62.5 \\
\hline & NGRIP $2079.40 \mathrm{~m}^{*}$ & $2079.25-2079.40$ & 115 & GS-9 & $38826 \pm 1479$ & 21.7 & 37.5 \\
\hline & NGRIP 2081.95 m* & 2081.75-2081.95 & 9 & GS-9 & $38993 \pm 1491$ & 40.4 & 60.0 \\
\hline & NGRIP $2085.80 \mathrm{~m}^{*}$ & $2085.60-2085.80$ & 5421 & GS-9 & $39258 \pm 1510$ & 28.1 & 35.0 \\
\hline & GRIP $2213.05 \mathrm{~m}$ & $2212.85-2213.05$ & 176 & GS-9 & $39274 \pm 1511$ & 66.9 & 115.0 \\
\hline & NGRIP $2100.65 \mathrm{~m}^{*}$ & $2100.45-2100.65$ & 790 & GS-10 & $40218 \pm 1583$ & 64.6 & 67.5 \\
\hline & NGRIP $2101.55 \mathrm{~m}^{*}$ & $2101.45-2101.55$ & 11 & GS-10 & $40275 \pm 1587$ & 35.4 & 50.0 \\
\hline & NGRIP $2103.98 \mathrm{~m}^{* \wedge \#}$ & $2103.92-2103.98$ & 64 & GS-10 & $40428 \pm 1595$ & 30.8 & 50.0 \\
\hline & GRIP $2227.15 \mathrm{~m}^{\wedge}$ & 2226.95-2227.15 & 44 & GS-10 & $40433 \pm 1596$ & 59.3 & 107.5 \\
\hline & NEEM $1780.20 \mathrm{~m}^{\star \#}$ & $1780.00-1780.20$ & 12 & GS-10 & $40449 \pm 1596$ & 26.9 & 35.0 \\
\hline & GRIP $2227.90 \mathrm{~m}$ & 2227.70-2227.90 & 167 & GS-10 & $40498 \pm 1599$ & 15.3 & 37.5 \\
\hline & NEEM $1784.46 \mathrm{~m}$ & $1784.45-1784.46$ & 1178 & Gl-10 & $40915 \pm 1619$ & 13.4 & 25.0 \\
\hline & DYE-3 $1895.55 \mathrm{~m}$ & 1895.45-1895.55 & 6 & GI-8 & $37600 \pm 1450$ & 47.5 & 80.0 \\
\hline & DYE-3 $1898.65 \mathrm{~m}$ & $1898.60-1898.65$ & 3 & GS-9 & $38500 \pm 1480$ & 53.8 & 107.5 \\
\hline & DYE-3 $1900.80 \mathrm{~m}$ & $1900.70-1900.80$ & 7 & GS-9 & $39000 \pm 1500$ & 40.4 & 110.0 \\
\hline & DYE-3 $1901.80 \mathrm{~m}$ & $1901.70-1901.80$ & 10 & GS-9 & $39200 \pm 1510$ & 54.8 & 70.0 \\
\hline & DYE-3 $1904.10 \mathrm{~m}$ & $1904.00-1904.10$ & 28 & GS-9 & $39700 \pm 1550$ & 50.8 & 80.0 \\
\hline & DYE-3 $1904.15 \mathrm{~m}$ & $1904.10-1904.15$ & 50 & GS-9 & $39800 \pm 1560$ & 45.8 & 70.0 \\
\hline & DYE-3 $1912.35 \mathrm{~m}$ & $1912.25-1912.35$ & 4 & Gl-11 & $42300 \pm 1700$ & 36.7 & 70.0 \\
\hline
\end{tabular}




\begin{tabular}{|c|c|c|c|c|c|c|c|}
\hline & Tephra layer & $\begin{array}{l}\text { Depth Range } \\
\text { (m) }\end{array}$ & $\begin{array}{c}\text { Shards per } \\
\text { Sample }\end{array}$ & $\begin{array}{c}\text { Climatic } \\
\text { Event }\end{array}$ & $\begin{array}{l}\text { Age of base } \pm \\
\text { MCE (yr b2k) }\end{array}$ & $\begin{array}{c}\text { Average } \\
\text { Grain Size } \\
(\mu \mathrm{m})\end{array}$ & $\begin{array}{l}\text { Max Grain } \\
\text { Size }(\mu \mathrm{m})\end{array}$ \\
\hline \multirow{8}{*}{$\begin{array}{l}\mathbf{+} \\
\mathbf{0} \\
\frac{\boldsymbol{0}}{\boldsymbol{\varphi}} \\
\frac{\mathbf{n}}{\mathbf{n}}\end{array}$} & NGRIP $2150.90 \mathrm{~m}$ & $2150.70-2150.90$ & 78 & Gl-11 & $43066 \pm 1727$ & 26.9 & 42.5 \\
\hline & NGRIP $2162.05 \mathrm{~m}$ & $2161.90-2162.05$ & 40 & GS-12 & $43683 \pm 1753$ & 34.3 & 50.0 \\
\hline & NGRIP $2162.60 \mathrm{~m}$ & $2162.45-2162.60$ & 21 & GS-12 & $43726 \pm 1755$ & 22.5 & 35.0 \\
\hline & NGRIP $2163.35 \mathrm{~m}$ & 2163.15-2163.35 & 73 & GS-12 & $43783 \pm 1757$ & 30.5 & 50.0 \\
\hline & NGRIP $2164.10 \mathrm{~m}$ & $2163.90-2164.10$ & 61 & GS-12 & $43840 \pm 1761$ & 35.7 & 55.0 \\
\hline & NGRIP $2185.70 \mathrm{~m}$ & $2185.50-2185.70$ & 827 & Gl-12c & $45221 \pm 1827$ & 28.1 & 50.0 \\
\hline & NGRIP $2186.80 \mathrm{~m}$ & $2186.60-2186.80$ & 175 & GI-12c & $45285 \pm 1830$ & 21.1 & 30.0 \\
\hline & NGRIP $2188.25 \mathrm{~m}$ & $2188.05-2188.25$ & 382 & Gl-12c & $45368 \pm 1836$ & 25.6 & 45.0 \\
\hline
\end{tabular}




\begin{tabular}{|c|c|c|c|c|c|c|c|}
\hline & NGRIP depth (m) & NEEM depth (m) & GRIP depth (m) & SC & SD & Period & $\begin{array}{l}\text { Age of be } \\
\text { MCE (yr }\end{array}$ \\
\hline 1 & $1881.95-1882.10$ & $1648.75-1648.90$ & & 0.981 & 0.453 & GS-4 & $28575 \pm$ \\
\hline \multirow{3}{*}{2} & $1895.23-1895.24$ & $1656.45-1656.50$ & & 0.979 & 3.569 & GS-5.1 & $29132 \pm$ \\
\hline & $1895.23-1895.24$ & & $2049.30-2049.50$ & 0.991 & 2.108 & GS-5.1 & $29132 \pm$ \\
\hline & & $1656.45-1656.50$ & $2049.30-2049.50$ & 0.983 & 2.822 & GS-5.1 & $29132 \pm$ \\
\hline \multirow{3}{*}{3} & $1908.50-1908.70$ & $1664.85-1664.95$ & & 0.985 & 1.887 & GS-5.1 & 30082 \\
\hline & $1908.50-1908.70$ & & $2060.70-2060.85$ & 0.978 & 2.688 & GS-5.1 & $30082 \pm$ \\
\hline & & $1664.85-1664.95$ & $2060.70-2060.85$ & 0.976 & 2.106 & GS-5.1 & 30082 \\
\hline 4 & $\begin{array}{l}1915.10-1915.50 \\
1915.50-1915.63 \\
\end{array}$ & 1669.10-1669.25 & & 0.977 & 2.681 & GS-5.1 & $30565=$ \\
\hline \multirow{3}{*}{5} & $1929.80-1929.95$ & $1677.50-1677.60$ & & 0.973 & 2.771 & GS-5.2 & $31432 \pm$ \\
\hline & $1929.80-1929.95$ & & $2079.00-2079.40$ & 0.976 & 2.941 & GS-5.2 & $31432 \pm$ \\
\hline & & $1677.50-1677.60$ & $2079.00-2079.40$ & 0.982 & 0.555 & GS-5.2 & $31432 \pm$ \\
\hline 6 & $1931.45-1931.60$ & & $2080.85-2081.05$ & 0.941 & 2.174 & GS-5.2 & $31543 \pm$ \\
\hline 7 & $1950.30-1950.50$ & $1689.05-1689.25$ & & 0.985 & 0.868 & GI-5.2 & $32463 \pm$ \\
\hline 8 & $1951.95-1952.15$ & $1690.15-1690.35$ & & 0.974 & 1.691 & GS-6 & $32522 \pm$ \\
\hline 9 & 1973.12-1973.16 & $1702.35-1702.40$ & & 0.987 & 2.857 & Gl-6 & $33686 \pm$ \\
\hline \multirow{3}{*}{10} & $2064.15-2064.35$ & $1755.45-1755.60$ & & 0.985 & 2.014 & $\mathrm{Gl}-8 \mathrm{c}$ & $38041 \pm$ \\
\hline & $2064.15-2064.35$ & & $2195.25-2195.45$ & 0.986 & 1.746 & Gl-8c & $38041 \pm$ \\
\hline & & $1755.45-1755.60$ & $2195.25-2195.45$ & 0.982 & 1.448 & Gl-8c & $38041 \pm$ \\
\hline \multirow{2}{*}{11} & $2066.95-2066.95$ & $1756.90-1757.10$ & & 0.995 & 4.151 & GI-8c & $38121 \pm$ \\
\hline & & $1756.90-1757.10$ & $2197.25-2197.45$ & 0.988 & 1.255 & GI-8c & $38121 \pm$ \\
\hline \multirow{3}{*}{12} & $2071.30-2071.50$ & $1759.65-1759.85$ & & 0.982 & 1.814 & GS-9 & $38309 \pm$ \\
\hline & $2071.30-2071.50$ & & $2201.10-2201.50$ & 0.972 & 1.103 & GS-9 & $38309 \pm$ \\
\hline & & $1759.65-1759.85$ & $2201.10-2201.50$ & 0.982 & 0.521 & GS-9 & $38309 \pm$ \\
\hline \multirow{3}{*}{13} & $2077.90-2078.01$ & $1764.05-1764.25$ & & 0.985 & 0.870 & GS-9 & $38735 \pm$ \\
\hline & $2077.90-2078.01$ & & $2206.60-2207.00$ & 0.985 & 1.971 & GS-9 & $38735 \pm$ \\
\hline & & $1764.05-1764.25$ & $2206.60-2207.00$ & 0.977 & 1.063 & GS-9 & $38735 \pm$ \\
\hline \multirow{3}{*}{14} & $2103.92-2103.98$ & $1780.00-1780.20$ & & 0.954 & 6.600 & GS-10 & $40428 \pm$ \\
\hline & 2103.92 - 2103.98 & & $2227.05-2227.10$ & 0.975 & 0.818 & GS-10 & $40428 \pm$ \\
\hline & & $1780.00-1780.20$ & $2227.05-2227.15$ & 0.977 & 1.614 & GS-10 & $40428 \pm$ \\
\hline
\end{tabular}





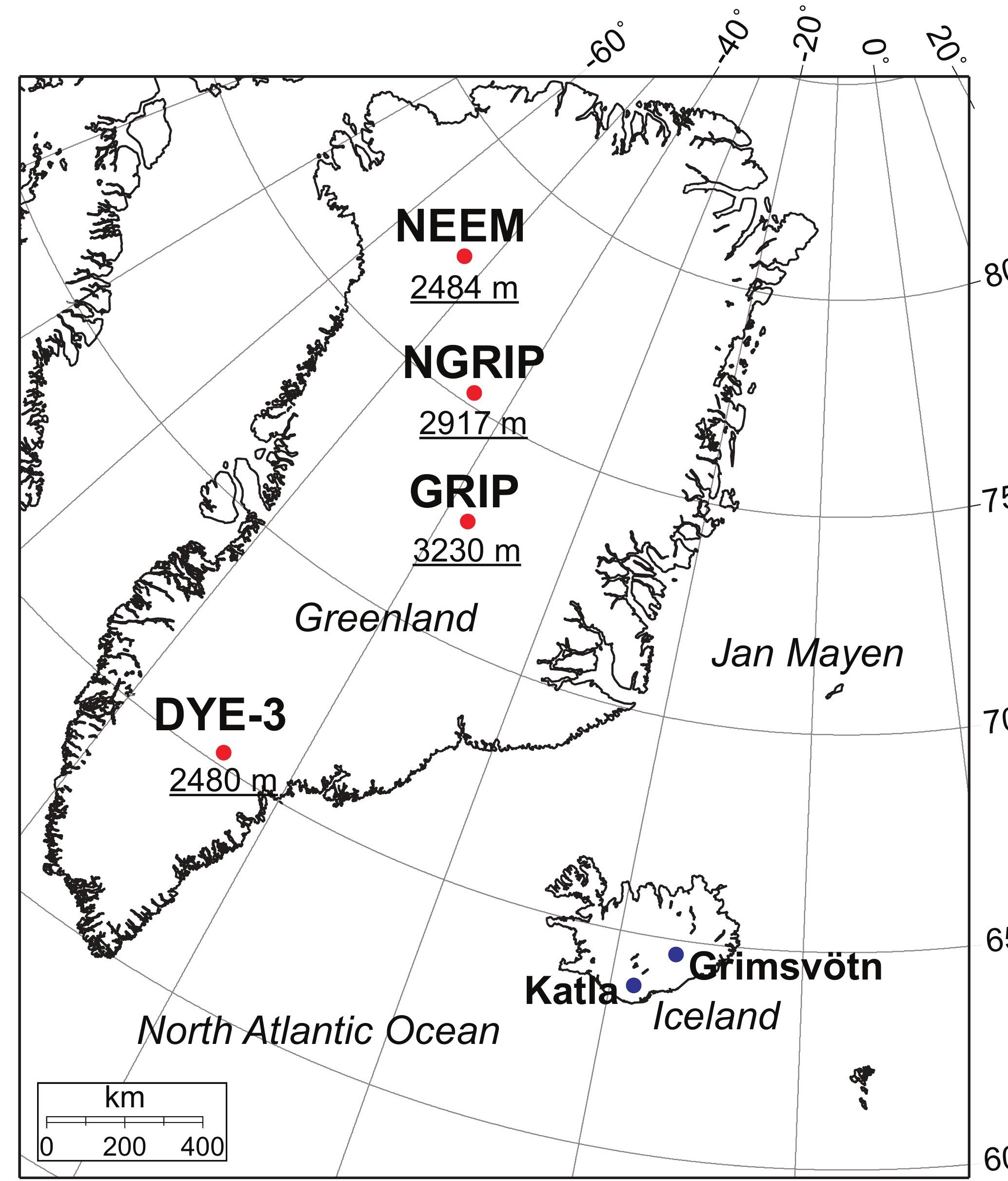




\section{Figure2}

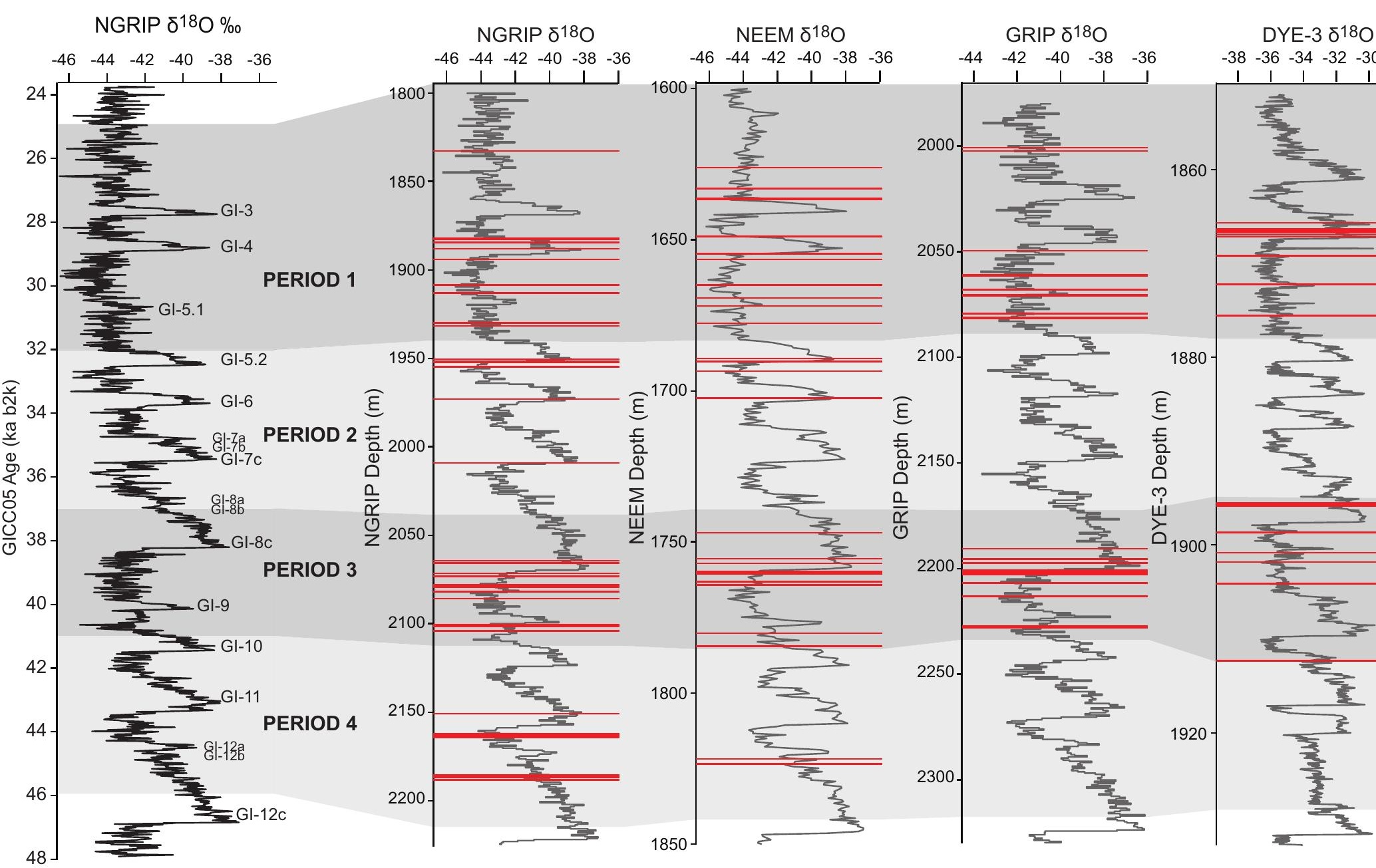




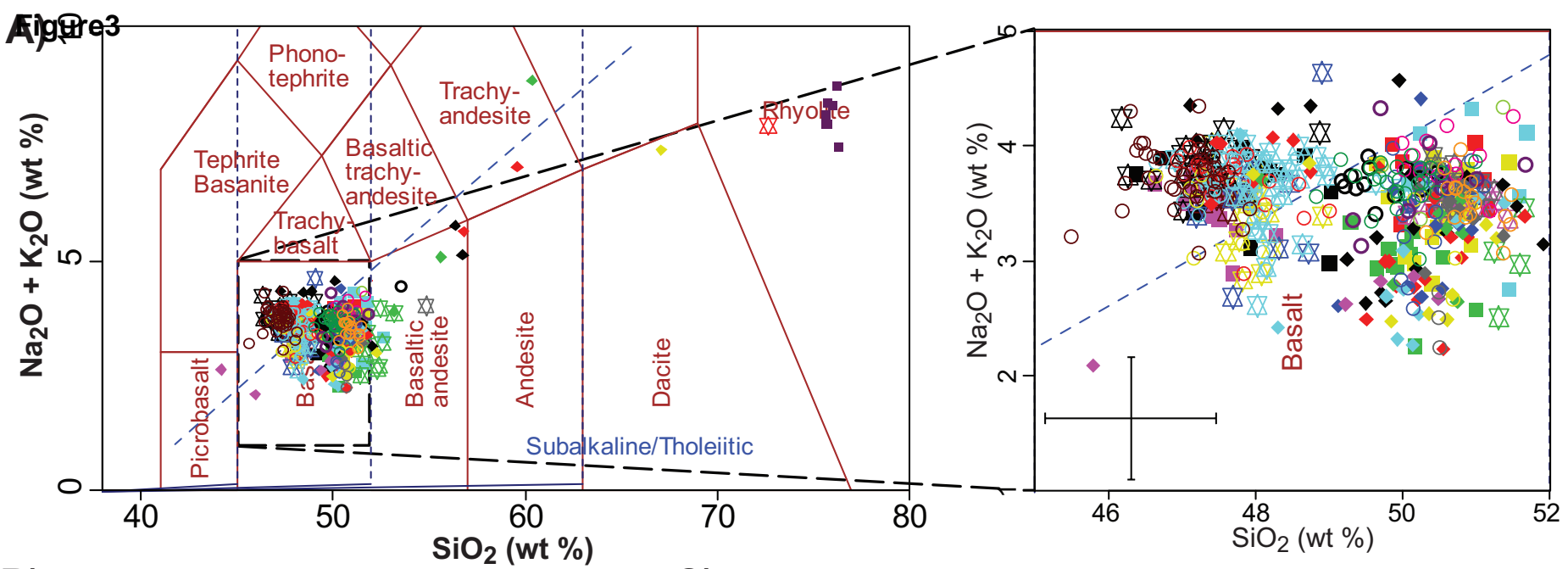

B)

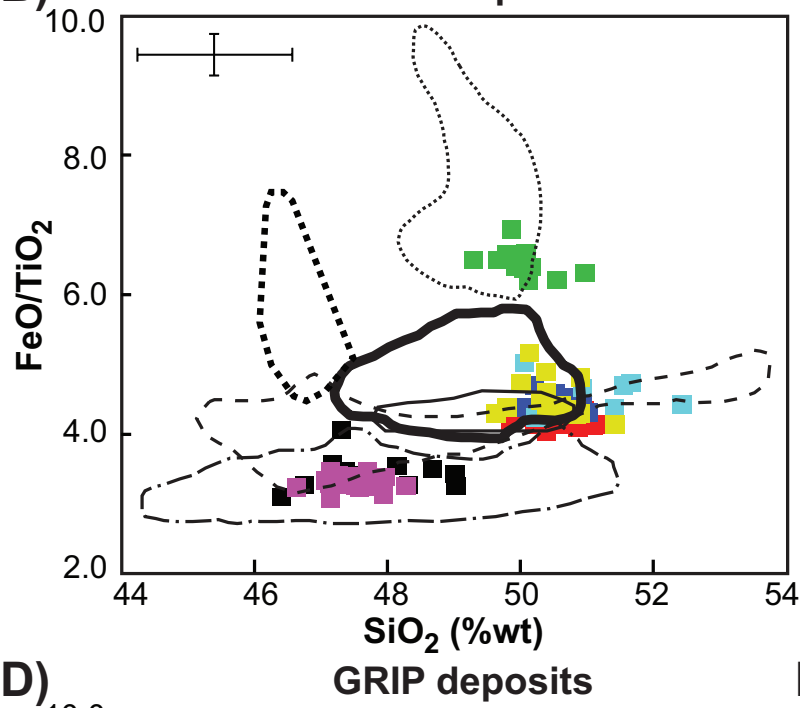

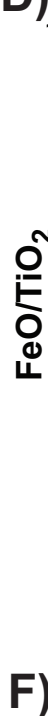

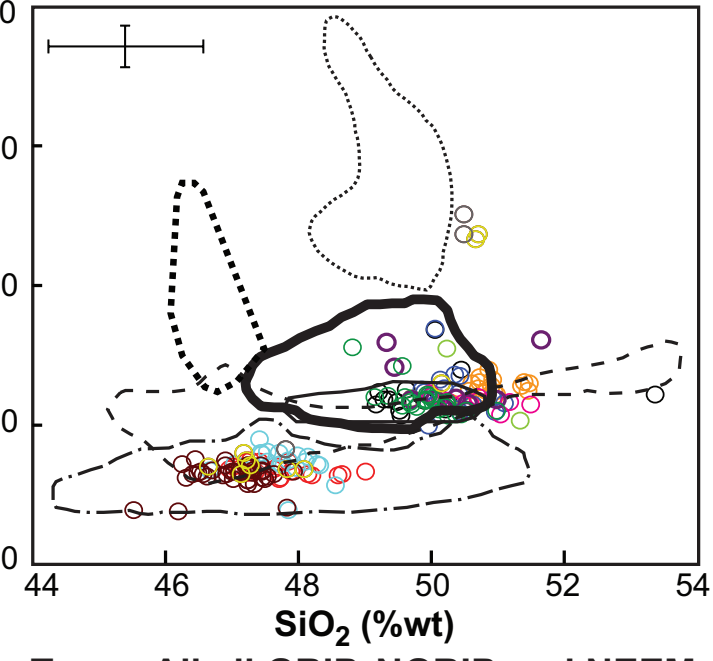

$\mathbf{F}$

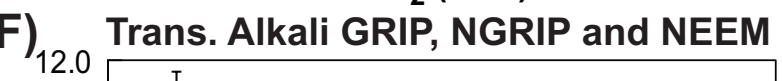

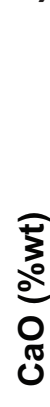
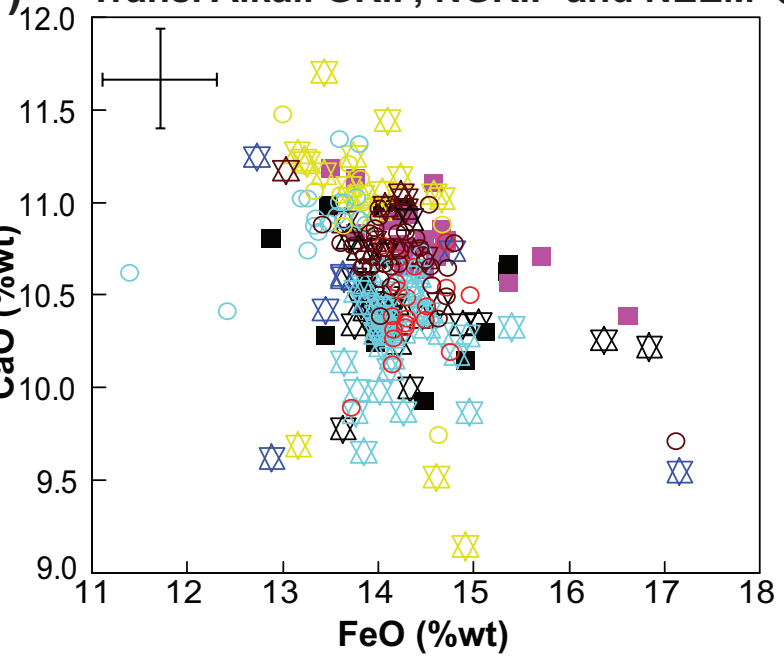

C)

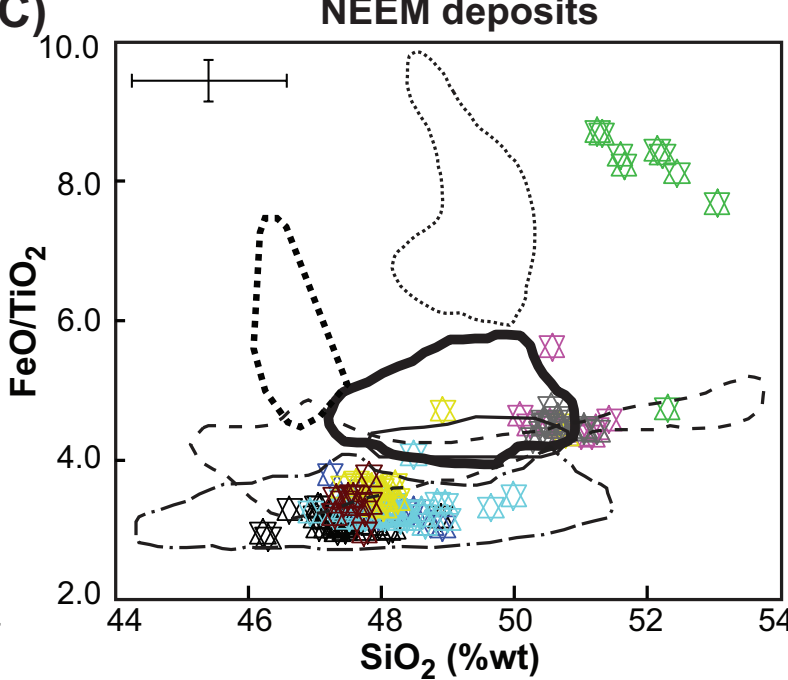

E)

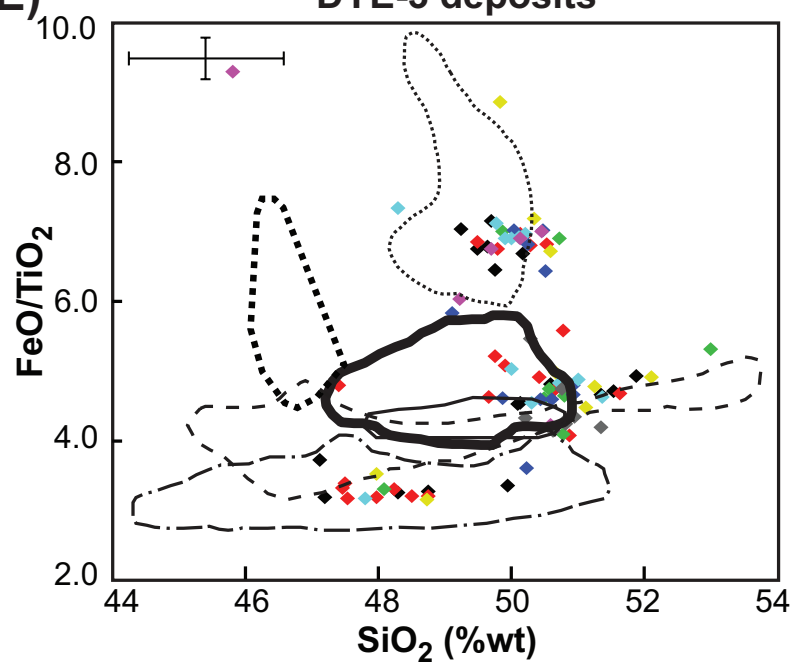

G) ${ }_{3.8}$ Tholeiitic GRIP, NGRIP and NEEM

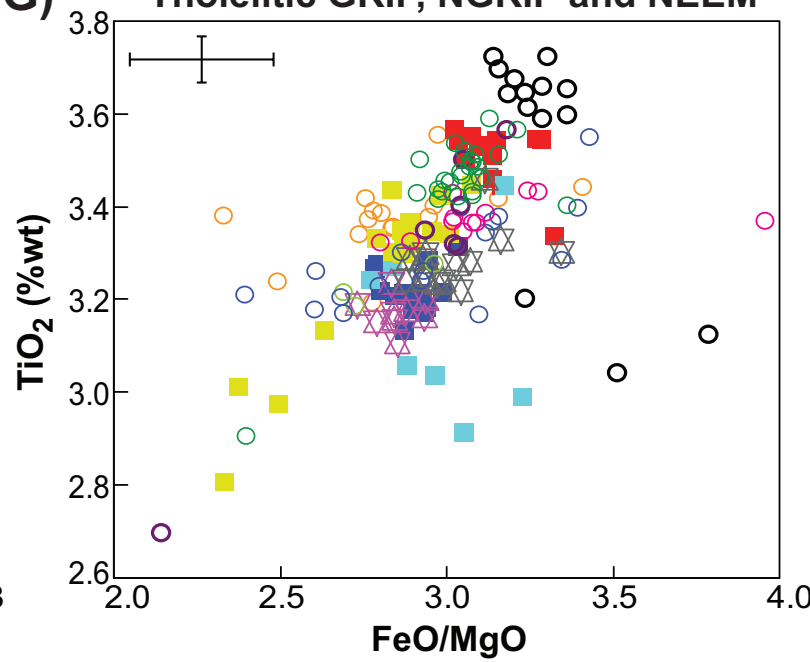

- DYE3 1865.70

- DYE3 1865.80

- DYE3 1865.90

- DYE3 1866.00

DYE3 1866.10

- DYE3 1866.40

DYE3 1866.60

- DYE3 1869.15

- GRIP2002.20

- GRIP2049.50

GRIP2060.85

GRIP2061.40

- GRIP2064.35

GRIP2066.75

- GRIP2067.85

GRIP2070.20

- GRIP2070.75

- GRIP2079.40

- GRIP2081.05

- GRIP2081.40

$\$$ NEEM1626.15

NEEM1636.45

$\triangle$ NEEM1636.65

$\$$ NEEM1648.90

NEEM1656.50

¿ NEEM1664.95

NEEM1669.25

\& NEEM1671.85

$\$$ NEEM1677.60

- NGRIP1882.10

- NGRIP1882.50

- NGRIP1888.10

- NGRIP1894.05

- NGRIP1908.70

- NGRIP1913.10

- NGRIP1929.95

NGRIP1931.60

Grimsvötn

_, Hekla/Vatnafjöll

(.) Katla

Kverkfjöll

Veidivötn

Vestmannaeyjar 


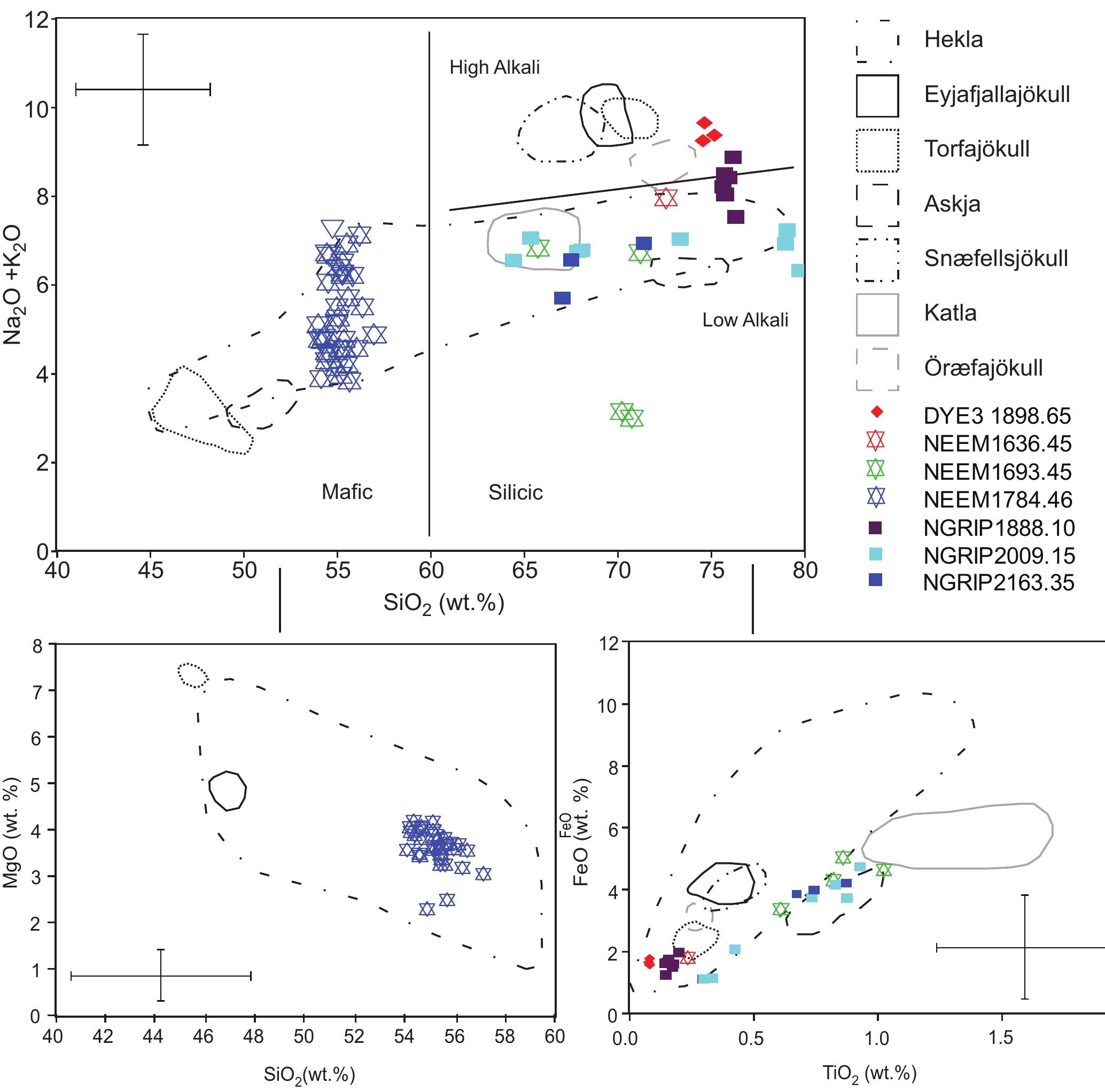


A)

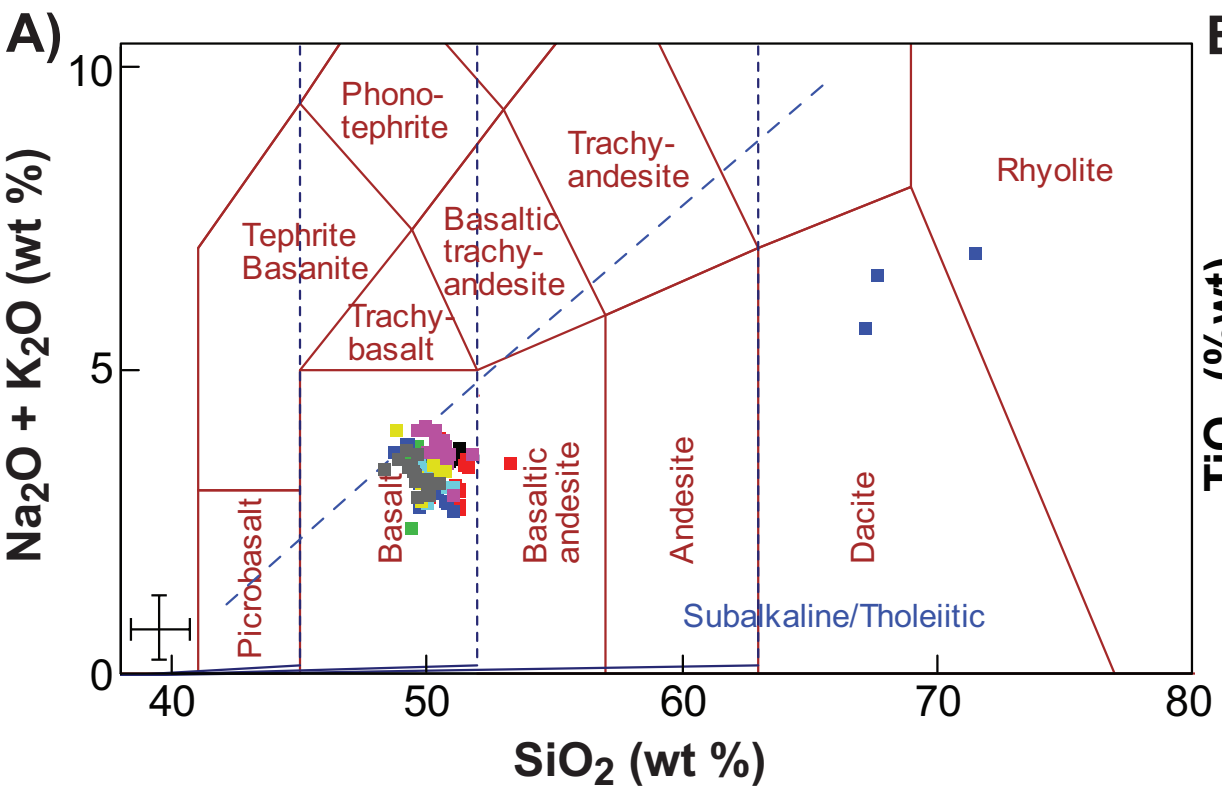

B)

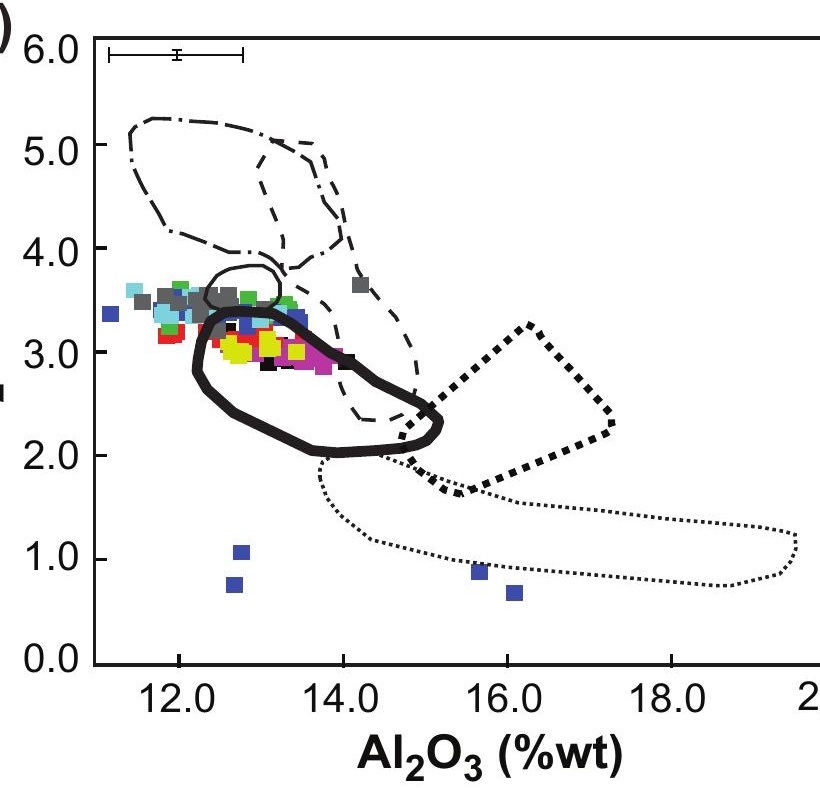

D)

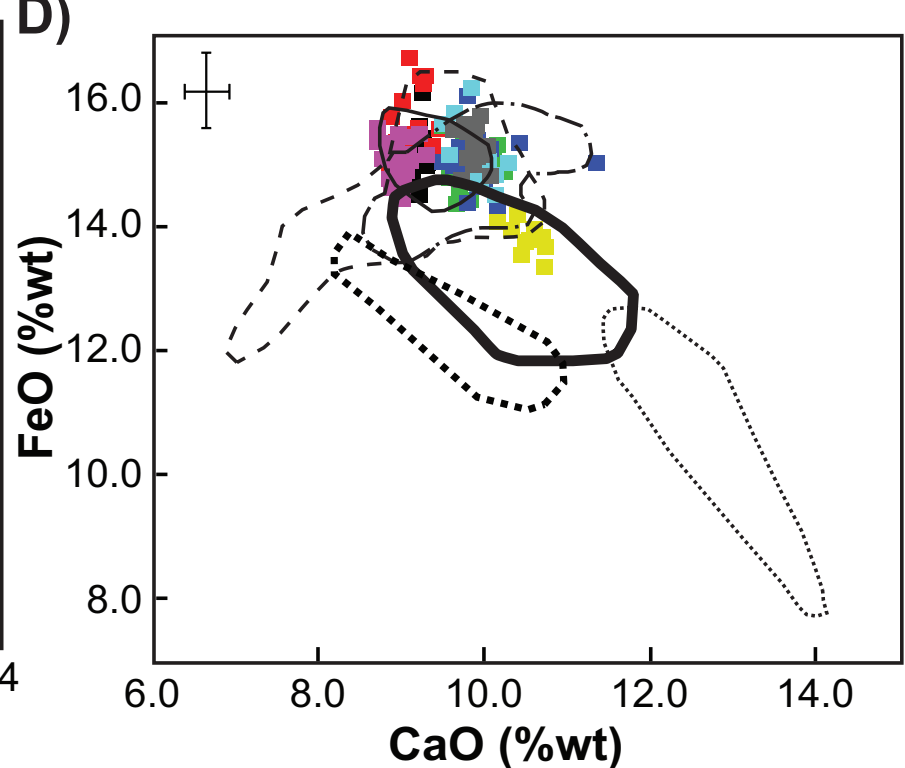

- NGRIP2150.

- NGRIP2162.C

- NGRIP2162.

- NGRIP2163.3

NGRIP2164.

- NGRIP2185.7

NGRIP2186.\&

- NGRIP2188.2

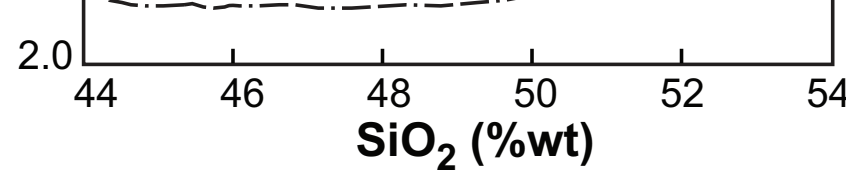

$\mathrm{SiO}_{2}$ (\%wt)

Grimsvötn Veidivötn Vestmannaeyja 

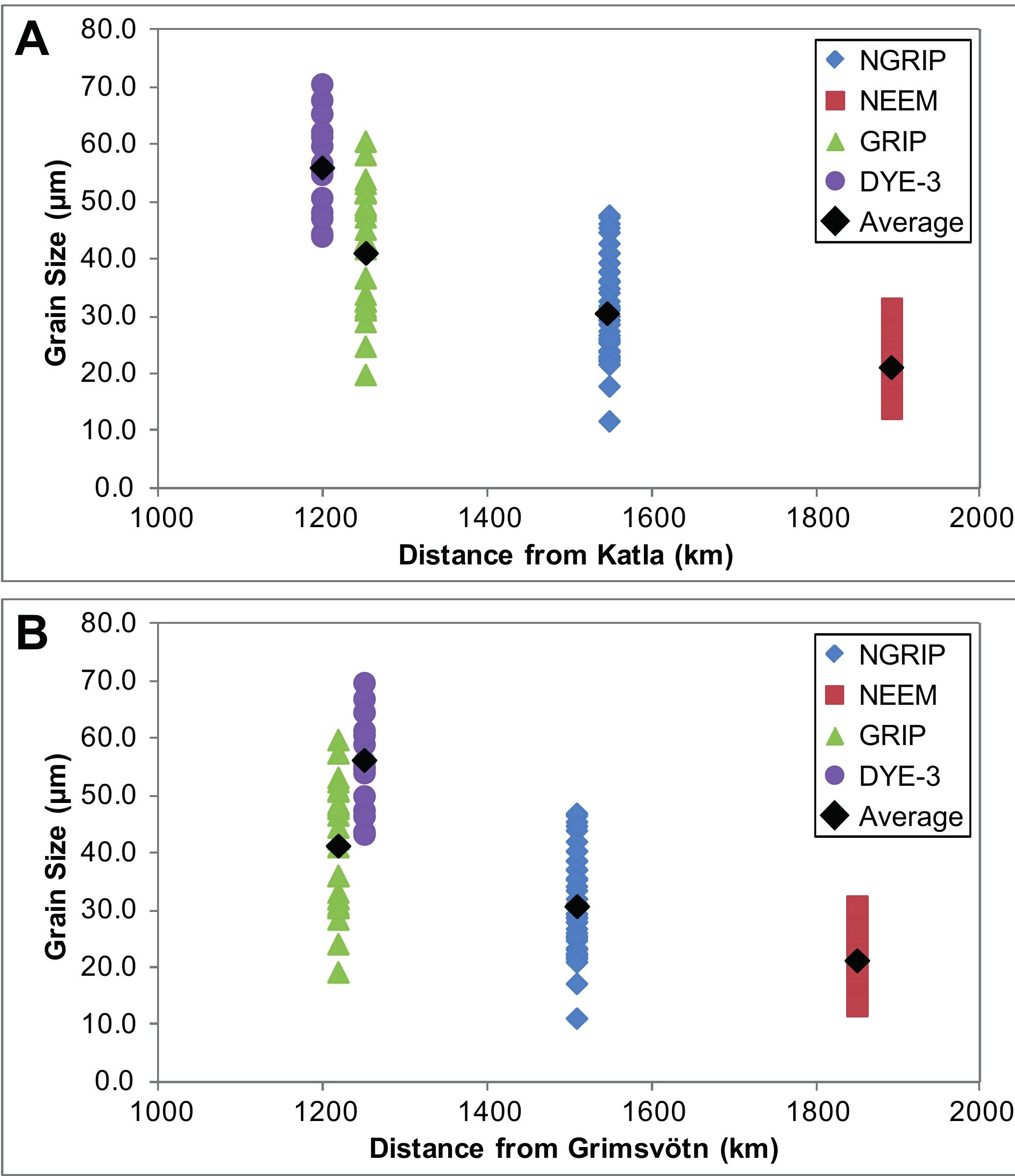


\section{A) gure12}

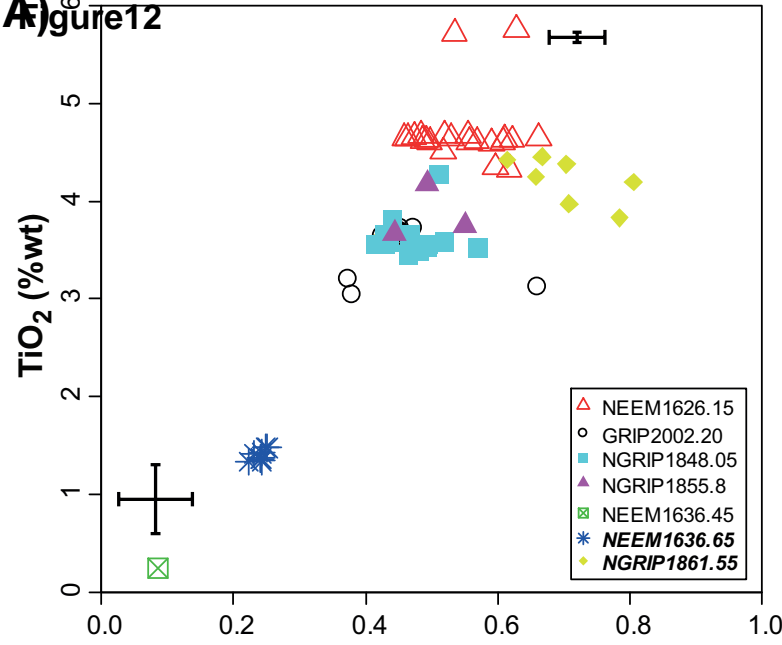

C)
B)

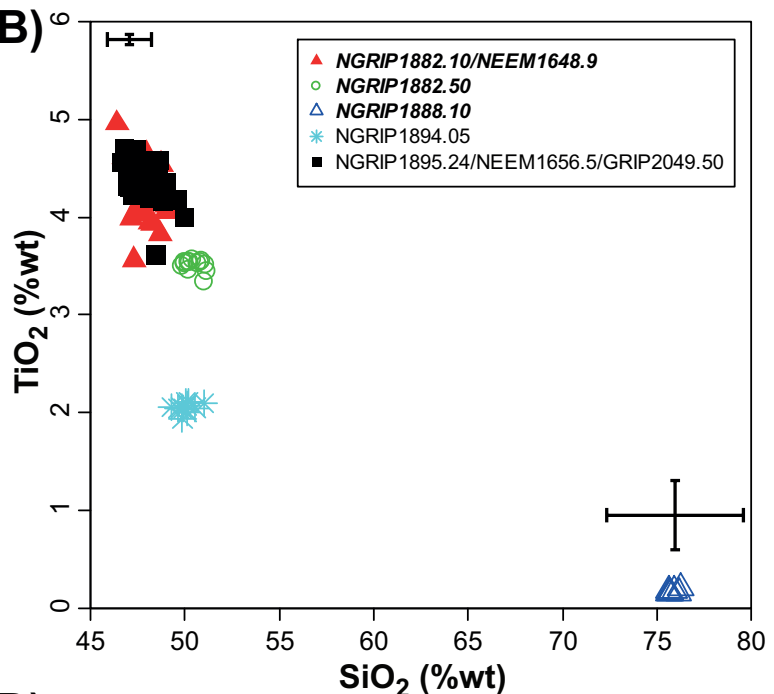

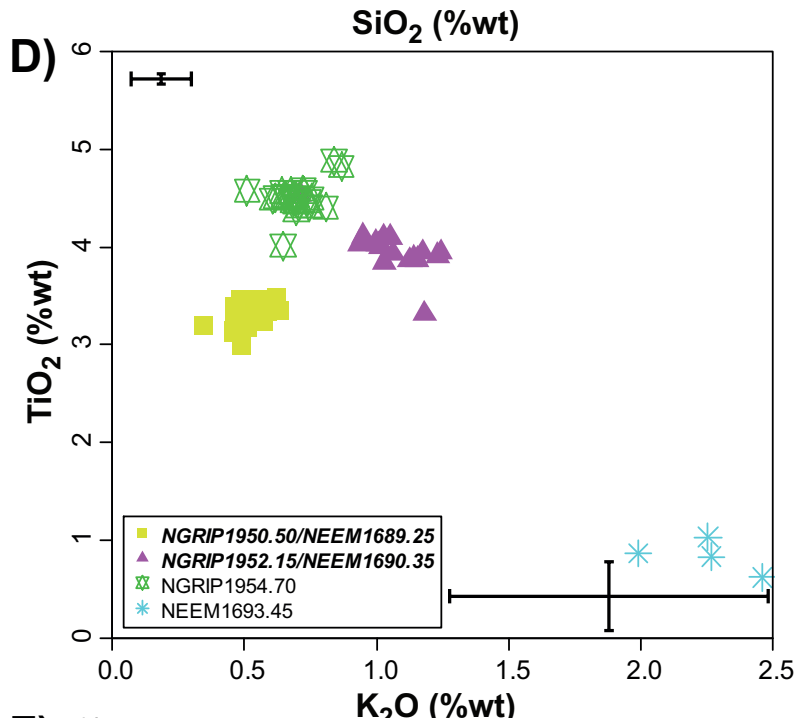

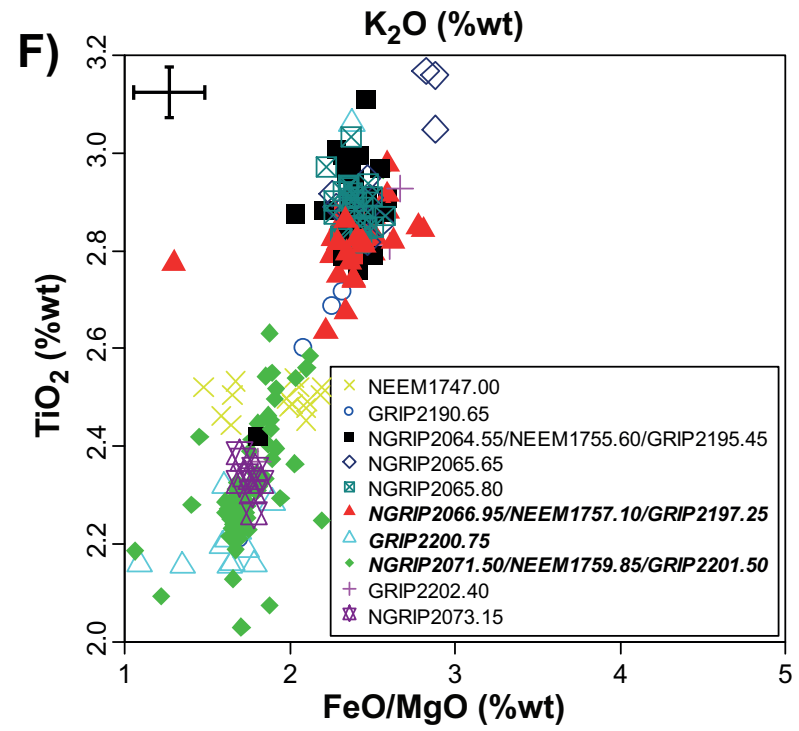

G)

$$
\text { (9) }
$$

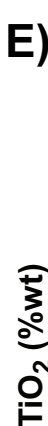$$
\mathrm{FeO} / \mathrm{MgO}(\% \mathrm{wt})
$$
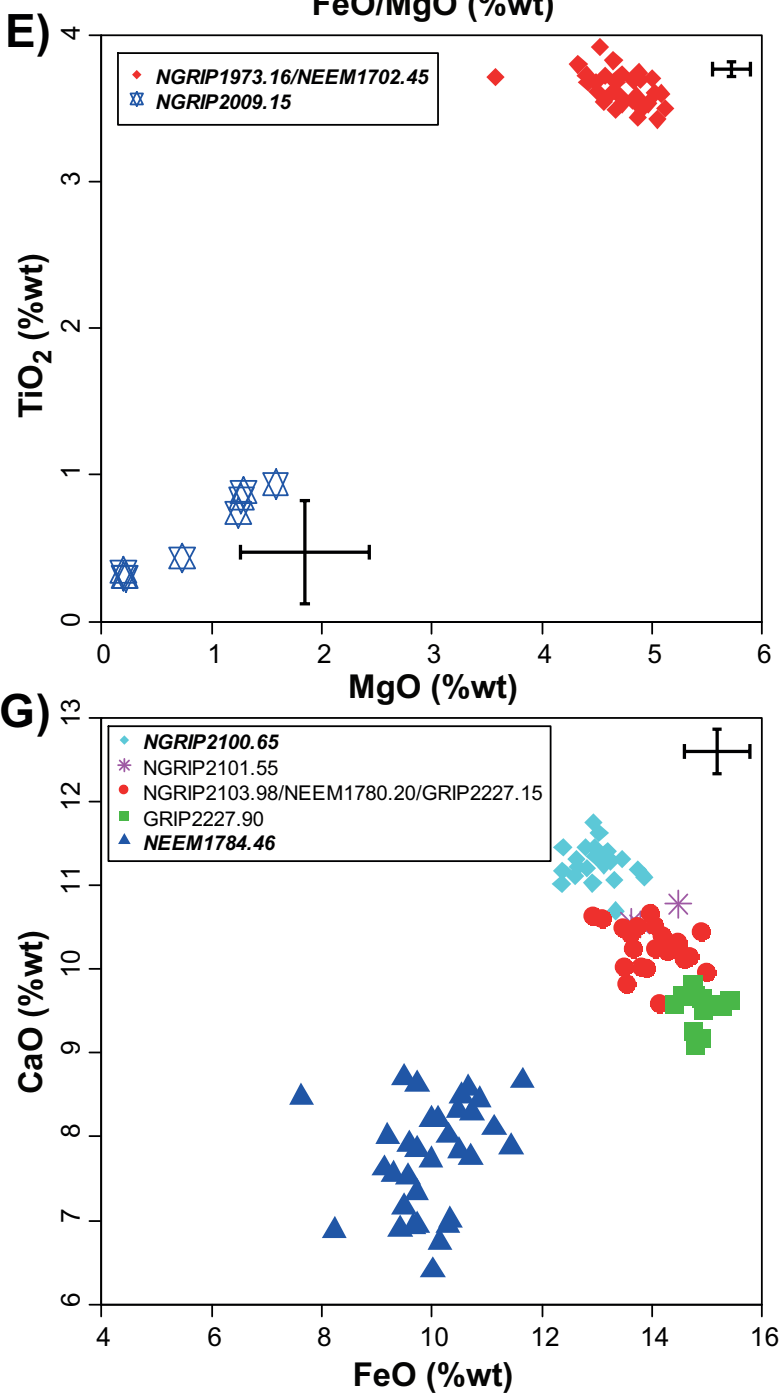
A)

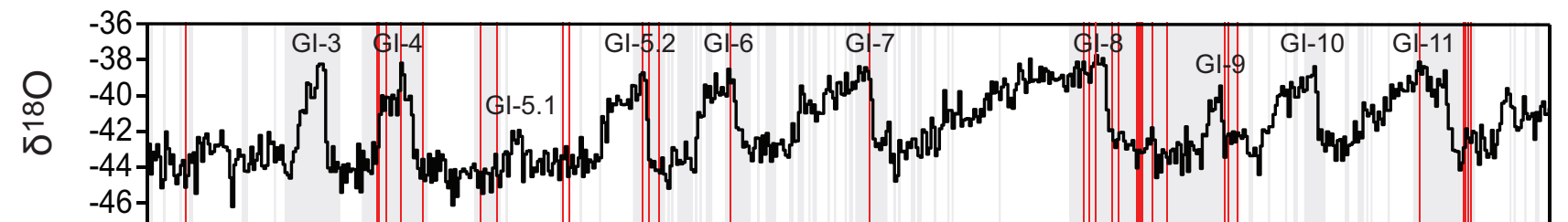

B)

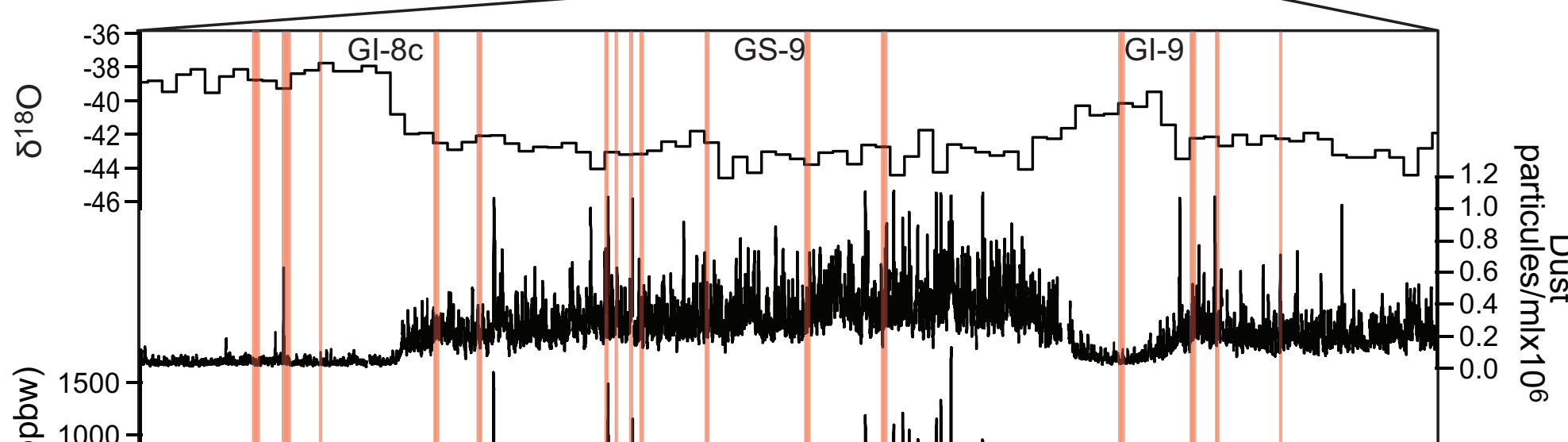

Ci)

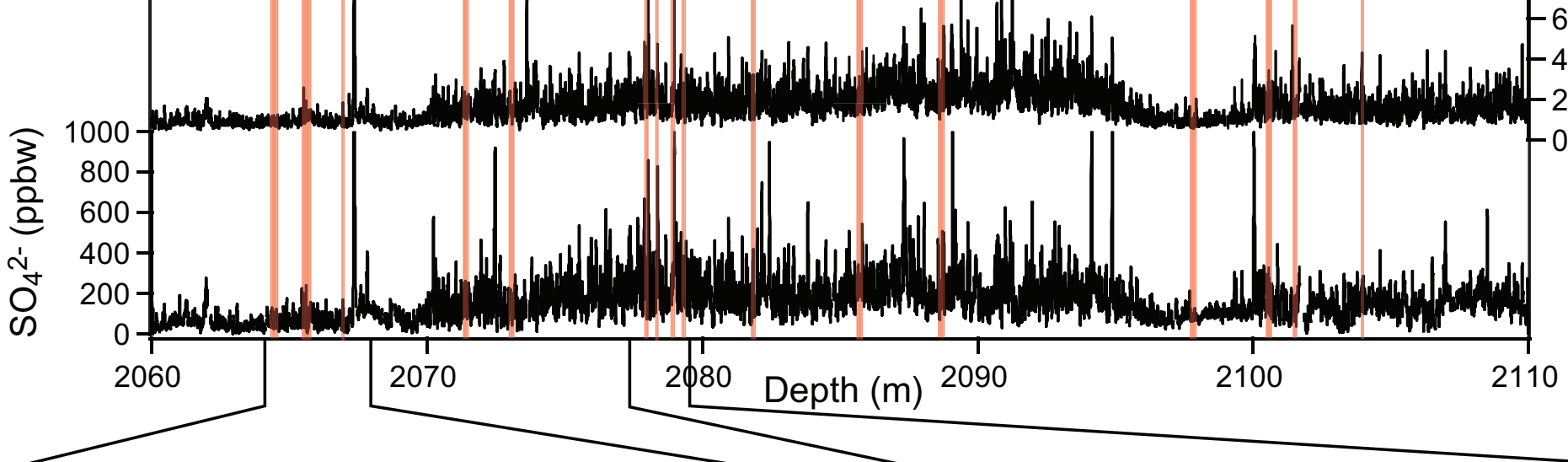

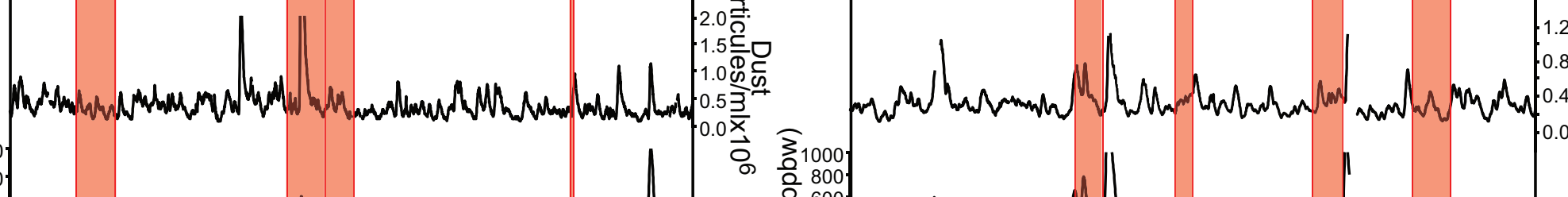

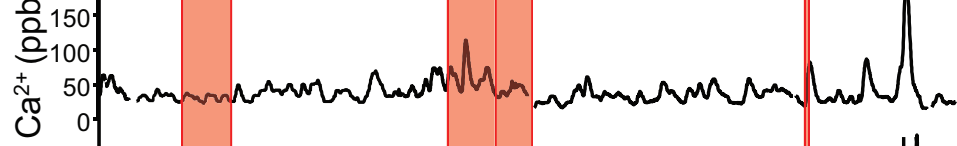

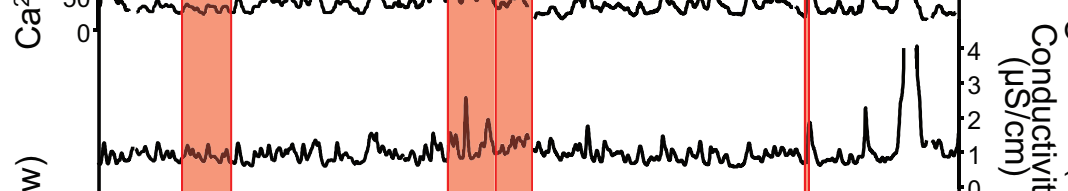

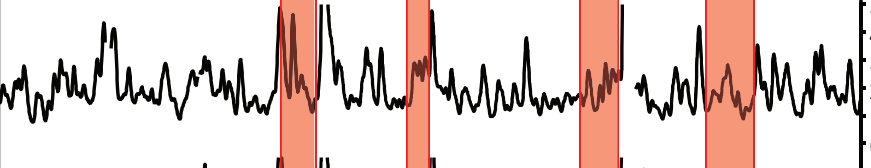

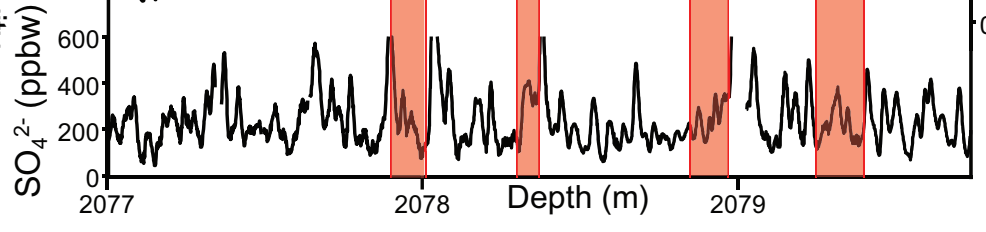




\section{Supplementary Data}

Click here to download Supplementary Data: Supplmentary Data.xls 